\title{
Economic Contributions of Agriculture, Natural Resources, and Related Industries in Florida in $2009^{1}$
}

\author{
Alan W. Hodges, Mohammad Rahmani, and Thomas J. Stevens ${ }^{2}$
}

\section{Executive Summary}

Agriculture, natural resources, and related industries remain a significant force in the economy of Florida, and it is important to recognize their economic contributions for informed public policy. The economic contributions of these industries were evaluated for 2009 to update previous reports and provide further information on economic trends in the wake of the historic global recession of 2007-2009. This analysis was conducted using the IMPLAN regional economic modeling system and associated state and county databases (MIG, Inc.) to estimate economic multipliers that capture the additional economic activity generated by re-spending of income in the local economy arising from new final demand. The set of industry sectors included in this analysis was selected to represent a broad array of linked activities for commodity production, manufacturing, distribution and supporting services. Economic contribution results for 2009 included the following:

- Industry output or sales revenues of $\$ 126.67$ billion, and total output impacts of $\$ 201.84$ billion, including indirect/induced multiplier effects arising from foreign and domestic exports of $\$ 49.78$ billion
- Direct employment of 1.30 million full-time and parttime jobs, representing 13.4 percent of all jobs in the state, and total employment impacts (including multiplier effects) of 1.94 million full-time and part-time jobs, which represents 20.0 percent of all jobs

- Direct value added of $\$ 60.64$ billion, representing 8.5 percent of Florida's Gross State Product, and total value added impacts (including multiplier effects) of \$107.21 billion, representing 15.1 percent of Gross State Product

- Total labor income impacts of $\$ 68.15$ billion for employee wages and benefits and business proprietor income, and total property income impacts of $\$ 27.24$ billion for rents, interest, royalties, and dividends

- Total indirect business tax impacts of $\$ 11.83$ billion paid to local, state, and federal governments

Total employment and value added impacts were largest for the Food and Kindred Products Distribution industry group (1.17 million jobs; $\$ 58.06$ billion), followed by Agricultural Inputs and Services (269,398 jobs; $\$ 14.23$ billion), Crop, Livestock, Forestry, and Fisheries Production (211,007 jobs; $\$ 10.08$ billion), Food and Kindred Product Manufacturing (147,424 jobs; $\$ 13.66$ billion), Forest Product Manufacturing

1. This is EDIS FE897, a publication of the Food and Resource Economics Department, Florida Cooperative Extension Service, Institute of Food and Agricultural Sciences, University of Florida, Gainesville, FL. Published August 2011. Please visit the EDIS website at http://edis.ifas.ufl.edu.

2. Alan W. Hodges, extension scientist, Mohammad Rahmani, economic analyst, and Thomas J. Stevens, post-doctoral research associate, Food and Resource Economics Department, Florida Cooperative Extension Service, Institute of Food and Agricultural Sciences, University of Florida, Gainesville, FL 32611. Corresponding author contact information: Email: awhodges@ufl.edu; Voice: (352) 392-1826 x312 [http://www.fred.ifas.ufl.edu/ economic-impact-analysis].

The use of trade names in this publication is solely for the purpose of providing specific information. UF/IFAS does not guarantee or warranty the products named, and references to them in this publication do not signify our approval to the exclusion of other products of suitable composition. 
(66,601 jobs; $\$ 5.73$ billion), Mining (41,054 jobs; $\$ 3.06$ billion), and Nature-based Recreation (41,451 jobs; $\$ 2.40$ billion). Excluding the Food and Kindred Products Distribution industry group, which includes food service establishments (restaurants and bars) and retail food stores, total economic impacts represented 6.9 percent of Gross State Product and 8.0 percent of total state employment.

Economic contributions were also evaluated for several commodity groups that have close linkages between production and processing/manufacturing sectors. The total value added and employment contributions were highest for the Environmental Horticulture group ( $\$ 8.45$ billion; 177,534 jobs), followed by Fruit and Vegetable Farming and Processing ( $\$ 6.96$ billion; 100,955 jobs), Forestry and Forest Products ( $\$ 6.56$ billion; 80,731 jobs), Livestock and Dairy Farming and Animal Products Manufacturing (\$906 million; 20,803 jobs), Sugarcane Farming and Refined Sugar Manufacturing (\$505 million; 17,092 jobs), Fishing and Seafood Products (\$277 million; 7,663 jobs), and Grain and Oilseed Farming and Processing (\$231 million; 3,015 jobs).

The makeup of agriculture, natural resources, and related industries varies dramatically across the state of Florida due to differences in climate, natural resource endowments, population, and settlement patterns. The largest economic contributions occurred in the major metro areas such as Miami-Ft. Lauderdale, Orlando, Tampa-St. Petersburg, Sarasota-Bradenton, and Jacksonville, where large demands for food and kindred products and a large workforce available for the industry co-exist. The eight largest counties in terms of total value added and employment impacts were Miami-Dade ( $\$ 13.40$ billion; 222,060 jobs), Hillsborough ( $\$ 11.17$ billion; 176,577 jobs), Orange ( $\$ 8.95$ billion; 165,063 jobs), Duval ( $\$ 8.60$ billion; 116,138 jobs), Broward ( $\$ 8.47$ billion; 153,557 jobs), Palm Beach ( $\$ 7.83$ billion; 147,681 jobs), Polk ( $\$ 6.18$ billion; 95,040 jobs), and Pinellas ( $\$ 4.89$ billion; 95,281 jobs). However, the economic contributions are also relatively important in rural areas, where agriculture and related industries may represent a higher share of total economic activity. Total value added impacts represented over 50 percent of Gross Regional Product in 3 Florida counties (Hamilton, Hardee, Glades) and 30-49 percent in 10 counties, while employment impacts represented over 50 percent of total employment in 4 Florida counties (Dixie, Hardee, DeSoto, Glades) and 30-49 percent in 10 counties. Additional detailed information on economic contributions in individual Florida counties is available at http://www.fred.ifas.ufl.edu/economic-impactanalysis/Florida-county-profiles-2009.pdf.
Direct employment in Florida's agriculture, natural resources, and related industries grew from 1.252 million jobs in 2001 to a peak of 1.382 million jobs in 2008, and then declined to 1.305 million jobs in 2009 as a result of the lingering effects of the global recession. This represented average annual job growth of 0.5 percent over the entire nine-year period, and 1.5 percent for the 2001-2007 period preceding the recession. Surprisingly, total employment impacts actually increased to the highest level ever in 2009, reflecting a dramatic increase in exports of Florida products to domestic and world markets and representing a 1.8 percent average annual growth during 2001-2009. Total value added impacts grew at a 4.9 percent average annual rate during 2001-2009, in inflation-adjusted terms. Among industry groups, average annual growth in value added impacts during 2001-2009 was highest for Agricultural Inputs and Services (14.9\%), followed by Mining (11.5\%) and Food and Kindred Products Distribution (6.7\%), while groups with low or negative growth during this period were Crop, Livestock, Fisheries, and Forestry Production (-1.4\%), Nature-based Recreation (-2.0\%), and Food and Kindred Product Manufacturing (1.6\%).

\section{Introduction}

Agriculture, natural resources, and related industries represent a major industry group in terms of generating employment and income, and producing goods and services that contribute to economic growth and development of Florida, and the United States. These industries utilize natural resources provided by the state's 24 million acres (36,000 square miles) of forests, croplands, and ranches to produce basic food, fiber, and mineral commodities. The unrefined commodities are converted into finished products by the food and kindred product manufacturing industries. Finished goods then move through the wholesale and retail distribution chain to final consumers or to other industry sectors as intermediate goods for further value-added processing. These industries are also linked to a broad array of allied suppliers that provide production inputs and supporting services. In addition, natural landscapes and other open or undeveloped lands provide an array of opportunities for nature-based recreation and eco-tourism. Thus, the chain of agricultural and related industry activities encompasses the whole of the concept "from farm to table."

Assessment of the economic contributions of regional industry activity is integral to making informed publicpolicy decisions regarding future economic and community development, job creation, environmental regulation, labor and human resources, and taxation. This report provides 
estimates of the economic contributions to the state of Florida in 2009 by a set of broadly defined industries comprising agriculture, natural resources, and related activities. It updates and continues a series of annual studies done previously for 2006, 2007, and 2008 (Hodges and Rahmani 2009, 2010; Hodges, Rahmani, and Mulkey 2008).

\section{Methods}

Data for this analysis were obtained from the IMPLAN3 database for the state of Florida and its counties for 2001-2009 (MIG, Inc.), which were derived from the National Income and Product Accounts for the United States (United States Department of Commerce, Bureau of Economic Analysis), the Quarterly Census of Employment and Wages (United States Bureau of Labor Statistics), and other sources. Over 90 individual industry sectors in the IMPLAN system were identified as related to agriculture and natural resource commodity production, input supply and supporting services, food and kindred product manufacturing, forest product manufacturing, food and kindred product distribution, and nature-based recreation. A list of industry groups and individual sectors included in the analysis is shown in Table 1. Note that some industry sectors in this analysis were reclassified from their original major industry group designation under the North American Industry Classification System (NAICS) to be included as part of the broadly defined agriculture-related industries categories. The rationale for including processing or manufacturing industries in this analysis is that they share a common dependence upon the natural resource base, and would not exist in the state if not for the basic production activities. Food and kindred product distribution sectors, such as wholesalers, food stores, and restaurants, although not strictly dependent upon natural resources, represent the end-point of the market chain for final consumers.

Economic contributions were also evaluated for several recognizable commodity groups that have linkages between production and processing/manufacturing sectors, including environmental horticulture (nursery and greenhouse production, landscape services, and retail lawn-and-garden centers); fruit and vegetable farming and processing; forestry, logging, and forest product manufacturing; sugarcane and refined sugar manufacturing; livestock and animal products manufacturing; and fishing and seafood products.

The total regional economic impacts for each sector were estimated using models developed with the IMPLAN3 software for social accounting and impact analysis (MIG, Inc.). This system enables construction of input-output models and social accounting matrices that represent the structure of a regional economy in terms of transactions among industry sectors, households, and governments. The IMPLAN model includes accounts for industrial commodity production, employment, labor and property income, household and institutional consumption, domestic and international trade (imports, exports), government taxes, transfer payments such as welfare and retirement, and capital investment. Economic multipliers are calculated for each industry to estimate the secondary effects of new final demand that generates further economic activity as it is respent in the local economy (Miller and Blair 2009). Indirect effects multipliers represent the economic activity generated in the supply chain through the purchase of intermediate inputs from vendor firms, while induced effects multipliers represent the impacts of spending by industry employee households and governments. The indirect and induced multipliers were applied only to foreign and domestic exports, or sales to customers visiting from outside the state of Florida, which represent new money flowing into the regional economy. The total economic impacts are calculated as the sum of direct effects, plus indirect and induced effects. Therefore, while the estimates of this analysis are referred to as "economic impacts," these values may be better understood as "economic contributions" because they represent the ongoing economic activity of existing industries, rather than a net change in activity resulting from external influences (Watson et al. 2007).

Measures of economic impacts reported here include output or revenue; value added; employment (including full-time, part-time, and seasonal positions); labor income; property income; and indirect business taxes paid to local, state, and federal governments. Value added is a broad measure of net economic activity that is comparable to the Gross Domestic Product (GDP), and represents the sum of labor and other property income, indirect business taxes, and capital consumption (depreciation). Value added also is equivalent to the difference between industry revenues and intermediate inputs purchased from other sectors. A glossary of economic impact analysis terminology is provided in the Appendix.

Regional economic models were developed for the state of Florida and for all 67 counties in the state using the IMPLAN3 software and Florida state/county data package for 2009 (MIG, Inc.). All model parameters were kept at default settings, with econometrically estimated regional purchase coefficients representing the share of commodities purchased from local sources, and social/institutional 
accounts included for households; local, state, and federal governments; and capital investment.

Summary information was developed for the state of Florida, all 67 counties, and 9 multi-county regions as shown in Figure 6. These functional economic areas represent core metropolitan areas and adjacent nonmetropolitan counties linked by employee commuting patterns, as defined by the United States Bureau of Economic Analysis (Johnson and Kort 2004). It should be noted that some Georgia counties included in the northern Florida regions were not evaluated in this analysis. Due to differences in trade flows and accounting adjustments at the state and county levels, slight discrepancies in regional results were reconciled by forcing county and regional estimates to match with state totals.

For some activities that were not specifically identified in IMPLAN, values were estimated as a share of their parent sector based on data from the 2007 Economic Census and previous special studies: Landscape services and Pest control services were 49 percent and 15 percent, respectively, of Services to buildings (sector 388); Wholesale food distribution was 20 percent of Wholesale trade (sector 319); Retail lawn-and-garden centers were 19 percent of Building materials and garden stores (sector 323); and Golf courses and Recreational fishing were 48 percent and 10 percent, respectively, of Amusement and recreation services (sector 410).

Employment figures reported represent all full-time, parttime, and temporary or seasonal jobs, rather than full-time equivalents. All monetary values were expressed in 2009 U.S. dollars using the mid-year (July) indices for the Gross Domestic Product (GDP) Implicit Price Deflator, which accounts for the effects of price changes in the measurement of GDP (United States Department of Commerce). Note that IMPLAN data were not available for 2005 . Note also that results for 2001-2008 were revised in light of new information, so findings presented here do not necessarily match those previously reported (Hodges and Rahmani 2009, 2010; Hodges, Rahmani, and Mulkey 2008).

\section{Results}

\section{Economic Contributions by Industry Groups and Sectors}

Economic contributions by major industry groups and specific industry sectors in Florida in 2009 are shown in Table 1 and summarized in Figures 1-3. The industries are categorized in seven major groups:
1. Crop, Livestock, Forestry, and Fisheries Production

\section{Mining}

3. Agricultural Inputs and Services

4. Food and Kindred Products Manufacturing

5. Forest Products Manufacturing

6. Food and Kindred Products Distribution

7. Nature-based Recreation

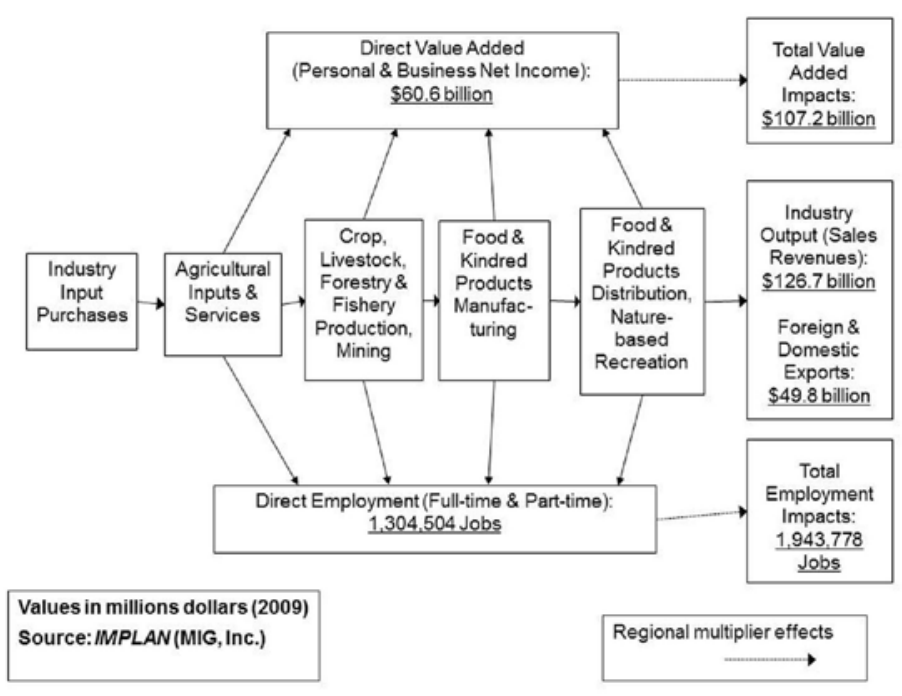

Figure 1. Structure of economic activity of agriculture, natural resources, and related industries in Florida, 2009

Results are reported below for each major group; for all groups combined; and for all groups, excluding Food and Kindred Products Distribution.

Direct industry output or sales in 2009 were $\$ 126.67$ billion. Foreign and domestic exports of goods and services to customers outside of Florida totaled $\$ 49.78$ billion. As a result of the indirect and induced multiplier effects arising from exports, an additional $\$ 75$ billion in output was generated in the economy, mostly in other economic sectors. The total output impacts, including direct, indirect, and induced effects, were estimated at $\$ 201.84$ billion. Direct employment in these industries was 1,304,504 full-time and part-time jobs, and total employment impacts (including multiplier effects) were estimated at 1,943,778 jobs. The direct value added impact of these industries was $\$ 60.64$ billion, and total value added impact was $\$ 107.21$ billion. The total labor (earned) income impact of employee wages and benefits and business proprietor income was $\$ 68.15$ billion. Total property income impacts, such as rents, interest, 
royalties, and dividends, amounted to $\$ 27.24$ billion. Total indirect business tax impacts paid to local, state, and federal governments were $\$ 11.83$ billion.

\section{Crop, Livestock, Forestry, and Fisheries Production}

includes sectors for the production of basic unrefined food and fiber commodities. In 2009, total output of these sectors was $\$ 9.81$ billion; exports were $\$ 6.03$ billion, and output impacts were $\$ 18.29$ billion (Table 1; Figure 2). Direct value added was $\$ 4.80$ billion and value added impacts were $\$ 10.08$ billion. Direct employment was 131,714 jobs and total employment impacts were 211,007 jobs (Figure 3). Labor income impacts were $\$ 6.86$ billion, other property income impacts were $\$ 2.63$ billion, and indirect business tax impacts were $\$ 587$ million. Among individual industry sectors in this group, the highest value added impacts were for Fruit farming ( $\$ 2.33$ billion); Greenhouse, nursery, and floriculture production ( $\$ 2.03$ billion); Vegetable and melon farming ( $\$ 1.93$ billion); and Support activities for agriculture and forestry (1.75 billion). The highest employment impacts were for Support activities for agriculture and forestry (59,392 jobs); Fruit farming (36,485 jobs); Greenhouse, nursery, and floriculture production (32,516 jobs); and Vegetable and melon farming (29,220 jobs). Large value added and employment impacts were also realized for the sectors of Forestry and timber tracts ( $\$ 592$ million; 8,660 jobs), Sugarcane farming ( $\$ 321$ million; 15,321 jobs), and Commercial logging ( $\$ 241$ million; 5,470 jobs). Value added impacts of \$100-\$200 million were observed for Commercial fishing, Cattle ranching and farming, Poultry and egg production, Dairy cattle and milk production, and All other crop farming.

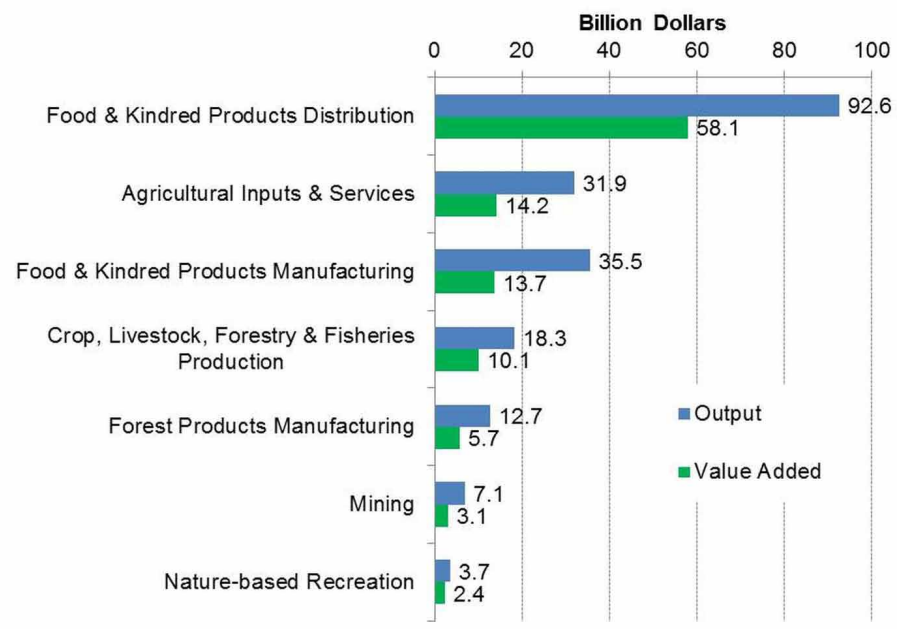

Figure 2. Output and value added contributions of agriculture, natural resources, and related industries in Florida, 2009. Source: IMPLAN data for Florida (Estimates include regional multiplier effects)

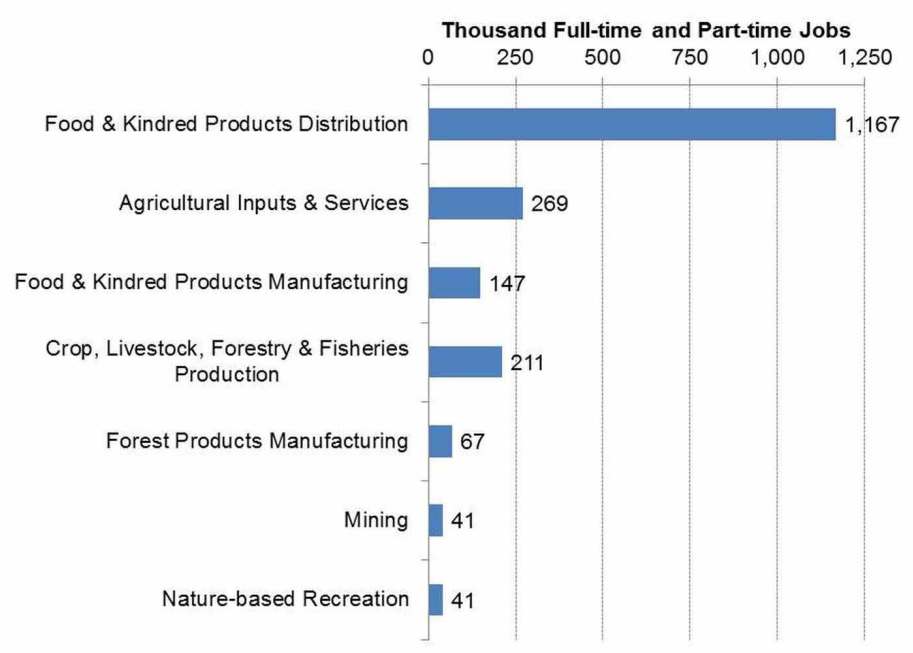

Figure 3. Employment contributions of agriculture, natural resources, and related industries in Florida, 2009. Source: IMPLAN data for Florida (Estimates include regional multiplier effects)

The Agricultural Inputs and Services group includes a variety of sectors providing inputs or support services for agricultural operations or landscape management. Output impacts in 2009 by this industry group totaled $\$ 31.92$ billion, including exports of $\$ 977$ billion (Table 1; Figure 2). Direct value added was $\$ 5.48$ billion and value added impacts were $\$ 14.23$ billion. Direct employment was 153,123 jobs and employment impacts were 269,398 jobs (Figure 3). Labor income impacts were $\$ 9.54$ billion, other property income impacts were $\$ 3.74$ billion, and indirect business tax impacts were $\$ 960$ million. Among leading sectors in this group, Landscape services had value added impacts of $\$ 5.51$ billion and employment impacts of 130,292 jobs, followed by Fertilizer manufacturing ( $\$ 5.64$ billion; 65,933 jobs), Pest control services ( $\$ 1.69$ billion; 39,885 jobs), Veterinary services ( $\$ 1.19$ billion; 31,054 jobs), and Pesticide and other agricultural chemical manufacturing (\$150 million; 1,599 jobs). Other minor sectors in this group included Farm machinery and equipment manufacturing, and Lawn and garden equipment manufacturing.

Mining relies upon natural resources for the extraction of basic mineral commodities such as oil, natural gas, stone, sand, gravel, clay, phosphate, and a variety of metals. In 2009, the Mining industries in Florida collectively had direct output of $\$ 3.98$ billion; exports of $\$ 2.14$ billion; output impacts of $\$ 7.08$ billion; direct employment of 15,446 jobs; employment impacts of 41,054 jobs; direct value added of $\$ 1.14$ billion; value added impacts of $\$ 3.06$ billion; labor income impacts of $\$ 1.67$ billion; other property income impacts of $\$ 1.16$ billion; and indirect business tax impacts of $\$ 225$ million (Table 1; Figures 2 and 3). The largest individual sector was Extraction of oil and 
natural gas, which had value added impacts of $\$ 1.29$ billion and generated employment impacts of 22,919 jobs. Other individual sectors with significant value added and employment impacts included Mining and quarrying of other non-metallic minerals (\$759 million; 6,687 jobs), Mining and quarrying of stone (\$346 million; 3,942 jobs), Mining and quarrying of sand, gravel, and clay (\$247 million; 3,166 jobs), and Drilling of oil and gas wells (\$228 million; 2,819 jobs). Other minor sectors in this industry group were Support activities for oil and gas operations; Mining gold, silver, and other metal ore; and Support activities for other mining.

\section{Food and Kindred Products Manufacturing industries} convert unrefined agricultural commodities to products for final consumption or use. In 2009, this group of industries in Florida had direct output of $\$ 22.40$ billion; exports of $\$ 10.87$ billion; output impacts of $\$ 35.54$ billion; direct employment of 40,795 jobs; total employment impacts of 147,424 jobs; direct value added of $\$ 5.73$ billion; value added impacts of $\$ 13.66$ billion; labor income impacts of $\$ 7.33$ billion; other property income impacts of $\$ 4.50$ billion; and indirect business tax impacts of $\$ 1.83$ billion (Table 1; Figures 2 and 3). This large industry group included 33 individual sectors, of which the highest value added and employment impacts were Soft drink and ice manufacturing ( $\$ 3.94$ billion; 51,946 jobs); Tobacco product manufacturing ( $\$ 2.73$ billion; 8,514 jobs); Fruit and vegetable canning, pickling, and drying ( $\$ 1.72$ billion; 23,330 jobs); Breweries ( $\$ 1.13$ billion; 10,174 jobs); Frozen Food Manufacturing (\$968 million; 12,664 jobs); and Other animal food manufacturing ( $\$ 625$ million; 7,590 jobs). Other sectors with significant value added impacts included Distilleries (\$397 million); Bread and bakery product manufacturing (\$322 million); All other food manufacturing (\$202 million); Flour milling and malt manufacturing (\$191 million); Sugarcane milling and refining (\$185 million); Fluid milk and butter manufacturing (\$176 million); and Coffee and tea manufacturing (\$165 million).

Forest Products Manufacturing is a group of industries for the processing of raw timber or wood into finished wood and paper products. In 2009, this industry group had direct output valued at $\$ 6.78$ billion; exports of $\$ 4.61$ billion; output impacts of $\$ 12.73$ billion; direct employment of 18,790 jobs; employment impacts of 66,601 jobs; direct value added of $\$ 2.14$ billion; value added impacts of $\$ 5.73$ billion; labor income impacts of $\$ 3.45$ billion; other property income impacts of $\$ 1.90$ billion; and indirect business tax impacts of $\$ 380$ million (Table 1; Figures 2 and 3). Leading sectors within this group in terms of value added and employment impacts were Paper mills ( $\$ 1.14$ billion; 12,813 jobs), Sanitary paper products manufacturing ( $\$ 1.09$ billion; 9,838 jobs), Paperboard container manufacturing ( $\$ 949$ million; 11,965 jobs), Paperboard mills (\$664 million; 6,906 jobs), Pulp mills (\$533 million; 6,085 jobs), and Stationary product manufacturing ( $\$ 249$ million; 3,183 jobs). Other sectors with significant value added impacts included Engineered wood member and truss manufacturing ( $\$ 217$ million), Coated and laminated paper packaging paper and plastics film manufacturing ( $\$ 170$ million), Wood window and door manufacturing (\$168 million), and Sawmills and wood preservation (\$152 million).

Nature-based Recreation includes recreational activities generally tied to natural resources or managed landscapes, such as golf, recreational fishing, and hunting and trapping. In 2009, this industry group in Florida had total output of $\$ 1.86$ billion; exports or sales to Florida visitors of $\$ 999$ million; output impacts of $\$ 3.70$ billion; direct employment of 25,398 jobs; employment impacts of 41,451 jobs; direct value added of $\$ 1.24$ billion; value added impacts of $\$ 2.40$ billion; labor income impacts of $\$ 1.53$ billion; other property income impacts of $\$ 646$ million; and indirect business tax impacts of $\$ 231$ million (Table 1; Figures 2 and 3). Among individual sectors, Golf courses had value added impacts of $\$ 1.92$ billion and employment impacts of 33,216 jobs, followed by Recreational fishing ( $\$ 400$ million; 6,920 jobs) and Commercial hunting and trapping (\$84 million; 1,315 jobs).

Food and Kindred Products Distribution includes activities for wholesale and retail trade in agricultural and related products. This large group of industry sectors is only indirectly related to agriculture and natural resources because it serves to deliver products to final consumers, but it is included here for perspective on the scope of the complex market chain for food and kindred products. In 2009, this industry group in Florida had total output of $\$ 64.64$ billion; exports of $\$ 15.37$ billion; output impacts of $\$ 92.58$ billion; direct employment of 919,239 jobs; employment impacts of 1,166,842 jobs; direct value added of $\$ 40.13$ billion; value added impacts of $\$ 58.06$ billion; labor income impacts of $\$ 37.78$ billion; other property income impacts of $\$ 12.67$ billion; and indirect business tax impacts of $\$ 7.62$ billion (Table 1; Figures 2 and 3). Collectively, this group represented about 54 percent of total value added impacts and 60 percent of employment impacts for all industries defined in this report. Among individual sectors within this group, Food service establishments and drinking places (restaurants and bars) had by far the greatest value added impacts ( $\$ 32.88$ billion) and employment impacts $(797,657$ 
jobs), followed by Wholesale trade in food and kindred products ( $\$ 13.57$ billion; 140,584 jobs), Food and beverage stores ( $\$ 10.71$ billion; 213,875 jobs), and Retail lawn and garden centers ( $\$ 902$ million; 14,726 jobs).

Excluding the sectors for Food and Kindred Products Distribution, total economic values for agriculture, natural resources, and related industries were a direct output of $\$ 62.03$ billion; exports of $\$ 34.41$ billion; output impacts of $\$ 109.26$ billion; direct employment of 385,265; employment impacts of 776,936 jobs; direct value added of $\$ 20.51$ billion; value added impacts of $\$ 49.15$ billion; labor income impacts of $\$ 30.37$ billion; property income impacts of $\$ 14.57$ billion; and indirect business tax impacts of $\$ 4.21$ billion (subtotal in Table 1).

\section{Economic Contributions by Commodity}

\section{Group}

In addition to the industry groups noted above, economic contributions were also evaluated for groups of food, fiber, and mineral commodities having identifiable market chain linkages between producers, manufacturers, and service sectors. In this section, some sectors are regrouped to reflect these linkages, with results summarized in Figures 4 and 5. Environmental Horticulture, which includes the sectors Nursery and greenhouse production, Landscape services, and Retail lawn and garden centers, had combined value added impacts of $\$ 8.45$ billion and employment impacts of 177,534 jobs. Fruit and Vegetable Farming and Processing, including sectors for Fruit farming; Vegetable and melon farming; Frozen food manufacturing; and Fruit and vegetable canning, pickling, and drying, had combined value added impacts of $\$ 6.96$ billion and employment impacts of 100,955 jobs. Forestry and Forest Products, including the sectors Forestry and timber tracts and Logging as well as 16 forest product manufacturing sectors, had combined value added impacts of $\$ 6.56$ billion and employment impacts of 80,731 jobs. Livestock and Dairy Farming and Animal Products Manufacturing, including the production sectors Beef cattle ranching and farming, Dairy cattle and milk production, Poultry and egg production, Animal production except cattle and poultry, Animal slaughtering, Poultry processing, Cheese manufacturing, and Ice cream manufacturing, had combined value added impacts of $\$ 906$ million and employment impacts of 20,803 jobs. Sugarcane Farming and Refined Sugar Manufacturing had combined value added impacts of $\$ 505$ million and employment impacts of 17,092 jobs. Fishing and Seafood Products combined had value added impacts of $\$ 277$ million and employment impacts of 7,663 jobs. The groups comprising Grain and Oilseed Farming and Processing had combined value added and employment impacts of \$231 million and 3,015 jobs, respectively.

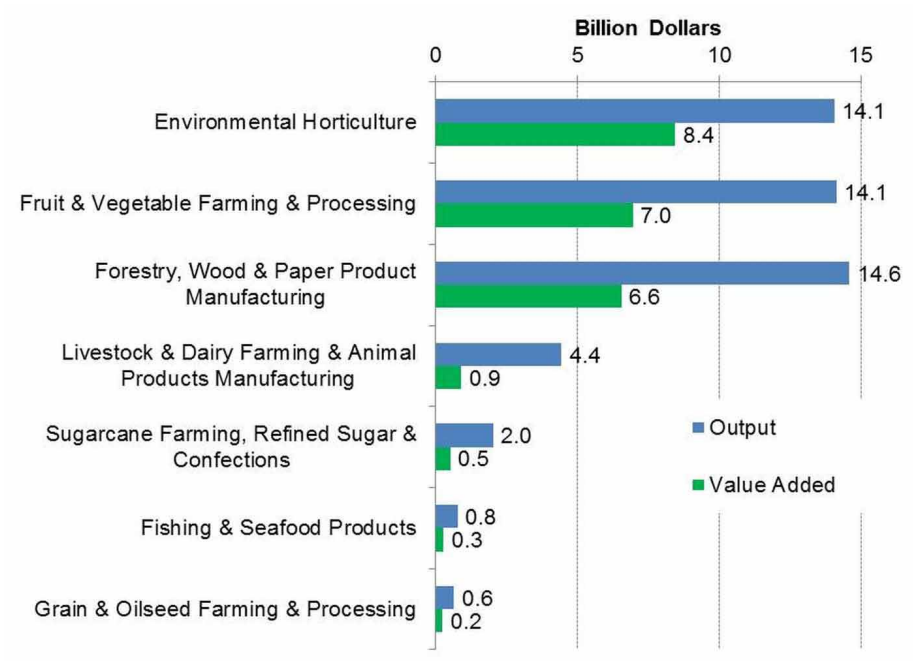

Figure 4. Output and value added contributions of food and fiber commodity groups in Florida, 2009. Source: IMPLAN data for Florida (Estimates include regional multiplier effects)

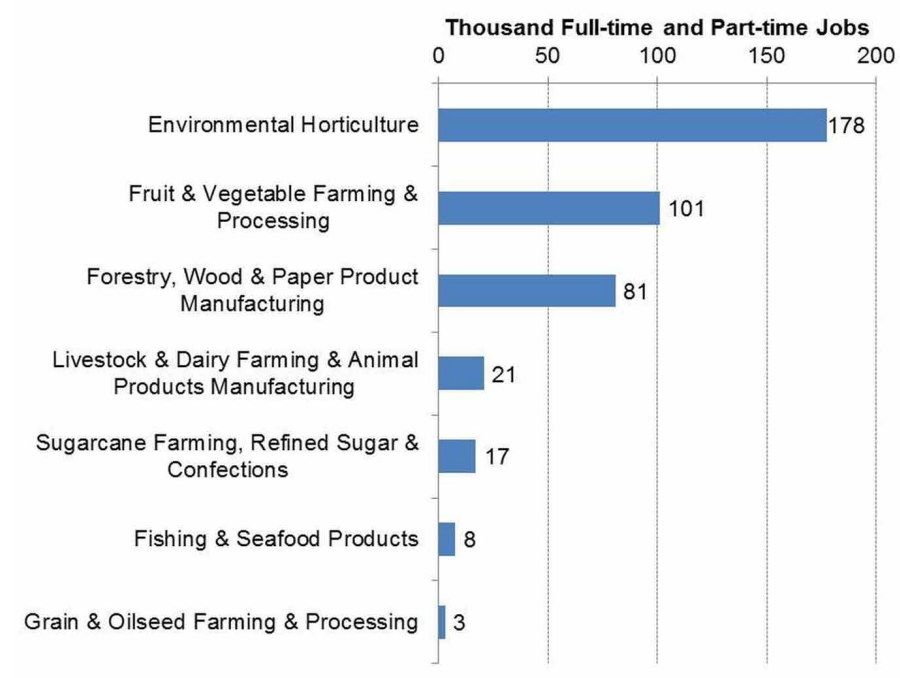

Figure 5. Employment contributions of food and fiber commodity groups in Florida, 2009. Source: IMPLAN data for Florida (Estimates include regional multiplier effects)

\section{Economic Contributions in Florida Regions and Counties}

Regional impacts of agriculture, natural resources, and related manufacturing, distribution, and service industries in 2009 were evaluated for all 67 Florida counties and each of the nine multi-county economic regions shown in Figure 6, with results summarized in Table 2, Figures 7 and 8 . The region with the highest value added and employment impacts was Miami-Ft. Lauderdale ( $\$ 34.77$ billion; 621,150 jobs), followed by Orlando ( $\$ 25.61$ billion; 477,963 jobs), 
Tampa-St. Petersburg ( $\$ 17.47$ billion; 305,684 jobs), Jacksonville ( $\$ 11.20$ billion; 163,025 jobs), Sarasota-Bradenton ( $\$ 9.20$ billion; 184,975 jobs), Pensacola ( $\$ 2.78$ billion; 59,479 jobs), Gainesville ( $\$ 2.67$ billion; 58,605 jobs), Tallahassee ( $\$ 2.19$ billion; 44,789 jobs), and Panama City (\$1.31 billion; 28,086 jobs).

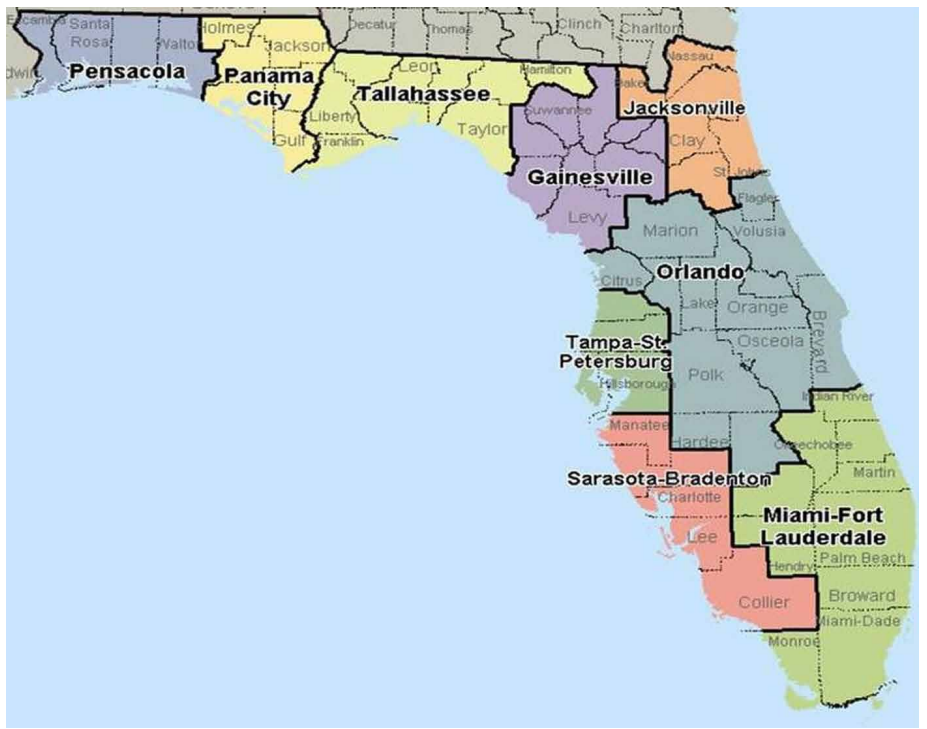

Figure 6. Functional economic regions of Florida. Source: Adapted from United States Commerce Department, Bureau of Economic Analysis (Johnson and Kort 2004)

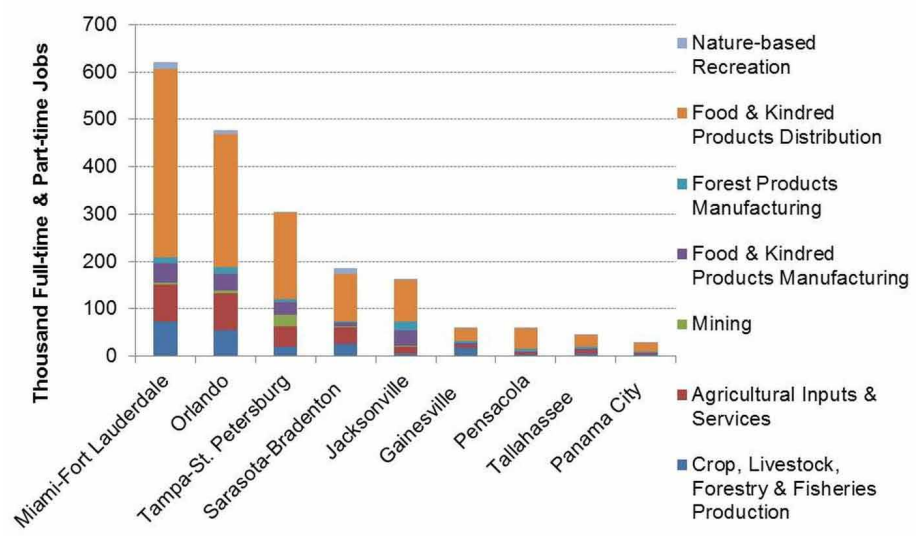

Figure 7. Employment contributions in Florida regions by agriculture, natural resources, and related industries, 2009. Source: IMPLAN data for Florida (Estimates include regional multiplier effects)

Among individual Florida counties, the eight largest counties in terms of value added impacts and employment impacts in 2009 were Miami-Dade ( $\$ 13.40$ billion; 222,060 jobs), followed by Hillsborough ( $\$ 11.17$ billion; 176,577 jobs), Orange ( $\$ 8.95$ billion; 165,063 jobs), Duval ( $\$ 8.60$ billion; 116,138 jobs), Broward ( $\$ 8.47$ billion; 153,557 jobs), Palm Beach ( $\$ 7.83$ billion; 147,681 jobs), Polk ( $\$ 6.18$ billion; 95,040 jobs), and Pinellas ( $\$ 4.89$ billion; 95,281 jobs). Eight other counties with value added impacts exceeding
$\$ 1$ billion were Lee ( $\$ 2.83$ billion), Collier ( $\$ 2.21$ billion), Manatee ( $\$ 2.15$ billion), Seminole ( $\$ 2.03$ billion), Volusia ( $\$ 1.74$ billion), Sarasota ( $\$ 1.56$ billion), Brevard ( $\$ 1.37$ billion), and Marion ( $\$ 1.22$ billion).

Additional detailed information on economic contributions in individual Florida counties is available at http://www. fred.ifas.ufl.edu/economic-impact-analysis/Florida-countyprofiles-2009.pdf.

\section{Share of Gross State Product and Employment}

The relative importance of agriculture, natural resources, and related manufacturing, distribution, and service industries in Florida can be gauged by their share of overall economic activity in the state. The Gross State Product (GSP) of Florida in 2009 was $\$ 712$ billion (equivalent to the sum of value added for all industries), and total employment in the state was $9,725,755$ million jobs. The direct value added contributed by agriculture, natural resources, and related industries ( $\$ 60.64$ billion) represented 8.5 percent of Florida's Gross State Product (Figure 8), while the total value added impact including regional multiplier effects ( $\$ 107.21$ billion) represented 15.1 percent of Gross State Product. Direct employment in the agricultural, natural resources, and related industries (1.30 million full-time and part-time jobs) represented 13.4 percent of all jobs in the state (Figure 9), while total employment impacts (1.94 million jobs), comprised 20.0 percent of all jobs. Excluding Food and Kindred Products Distribution, agriculture, natural resources, and related industries represented 2.9 percent of Gross State Product and 4.0 percent of total state employment.

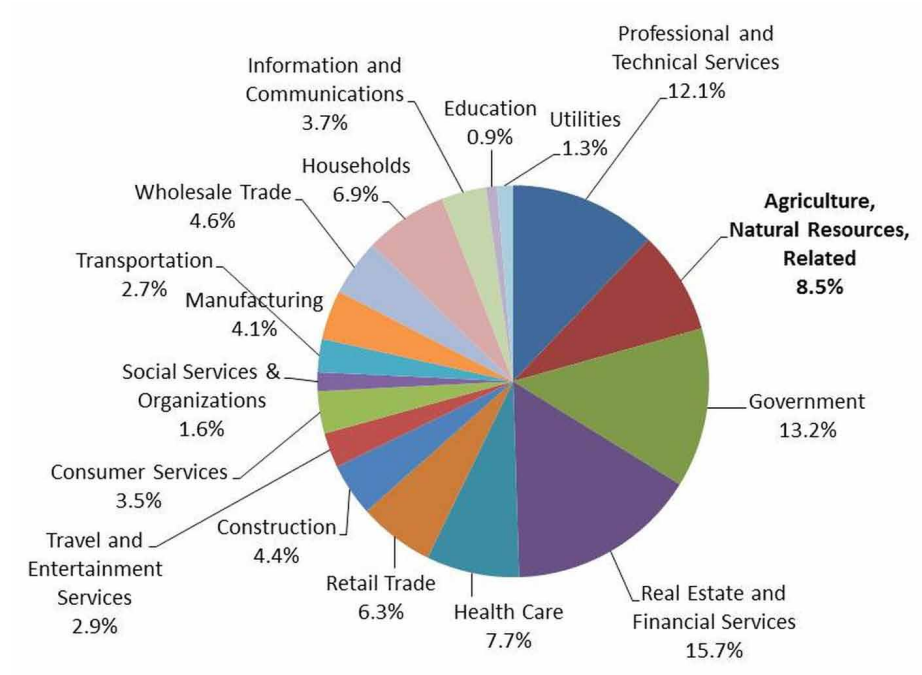

Figure 8. Direct value added by major industry groups as a share of Gross State Product of Florida in 2009. Source: IMPLAN data for Florida 


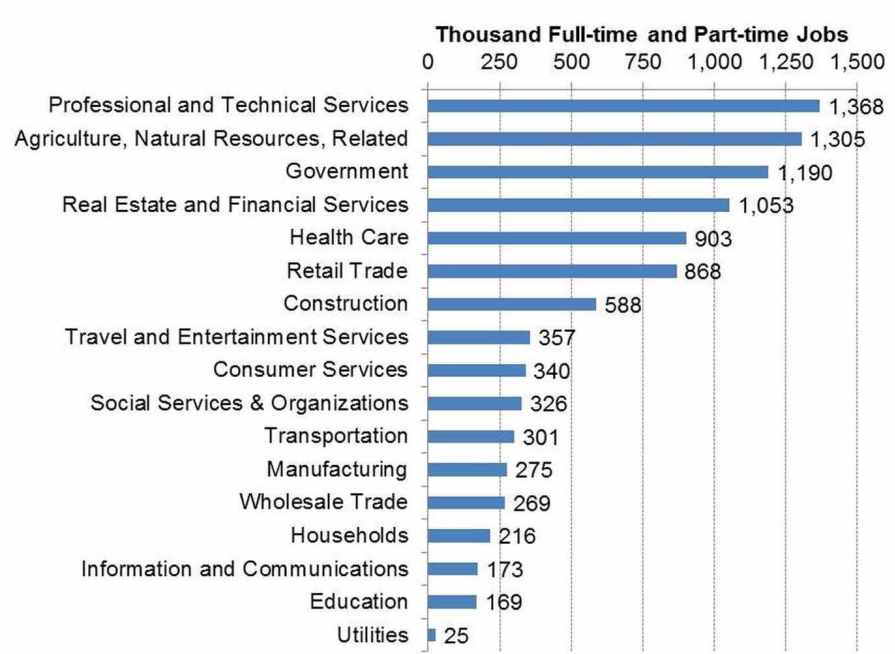

Figure 9. Direct employment by major industry groups in Florida in 2009. Source: IMPLAN data for Florida

At the county level, total value added impacts represented over 50 percent of Gross Regional Product in three Florida counties (Hamilton, Hardee, and Glades), 30-49 percent in ten counties, and 15-29 percent in twenty-one counties (Figure 10). Total employment impacts represented over 50 percent of total employment in four Florida counties (Dixie, Hardee, DeSoto, and Glades), 30-49 percent in ten counties, and 20-29 percent in twenty-three counties (Figure 11).

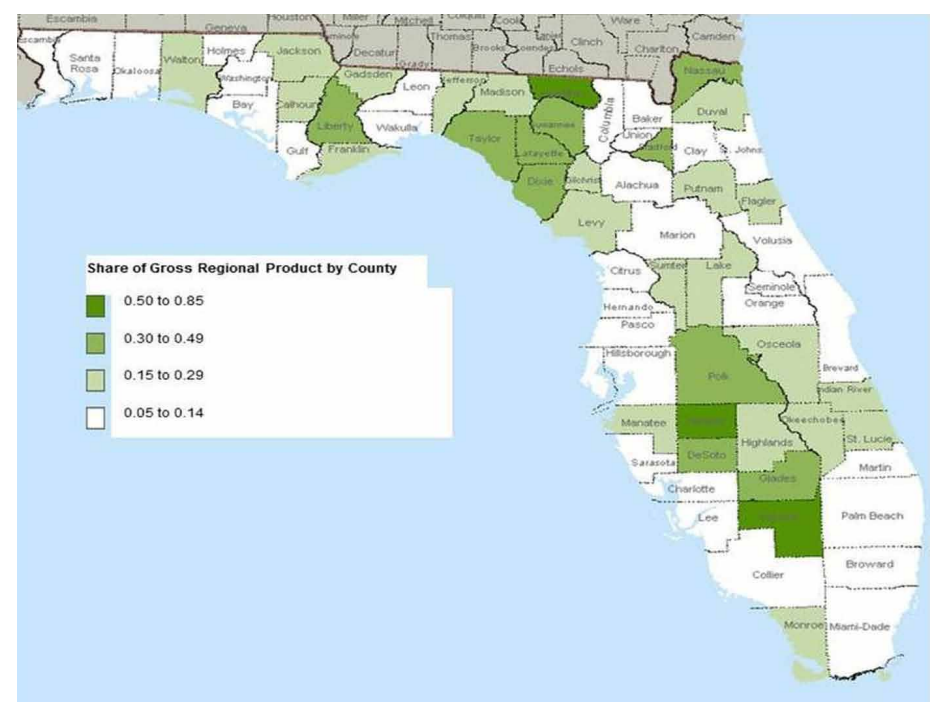

Figure 10. Map of contribution to Gross Regional Product in Florida counties by agriculture, natural resources, and related industries, 2009

\section{Trends in Economic Contributions}

In addition to the economic contributions in 2009, it is important to understand how these values have changed over time. Trends in the economic impacts of agriculture, natural resources, and related industries between 2001 and

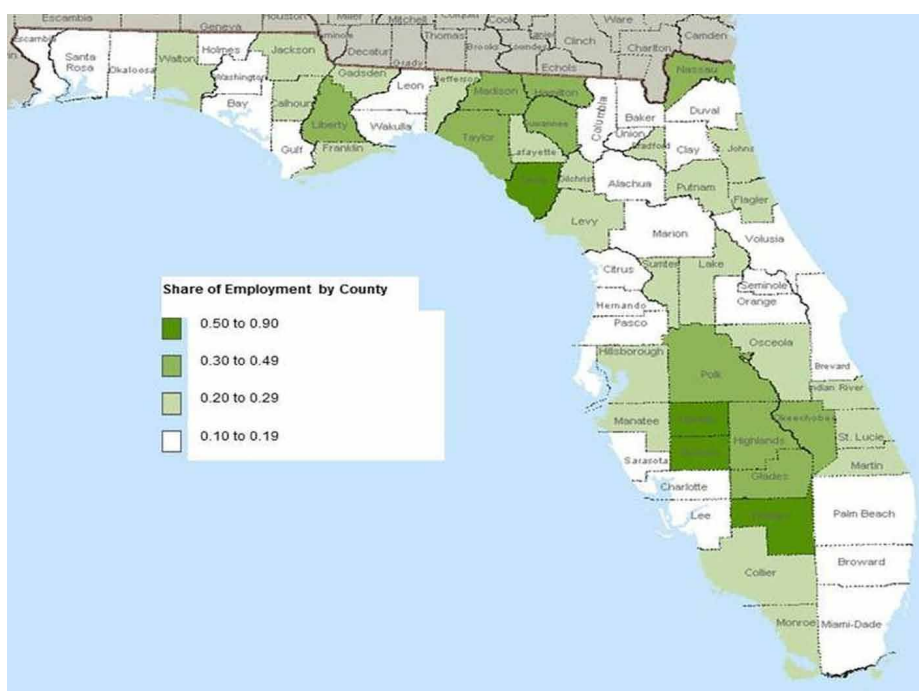

Figure 11. Map of contribution to total employment in Florida counties by agriculture, natural resources, and related industries, 2009

2009 are shown in Figures 12-14, with all monetary values adjusted for inflation and expressed in constant 2009 U.S. dollars. Note that these trends may also reflect changes in commodity prices and changes in the structure of the Florida economy as well as trends in economic activity due to the effects of recession and recovery.

Direct employment in Florida's agriculture, natural resources, and related industries grew from 1.252 million jobs in 2001 to a peak of 1.382 million jobs in 2008, and then declined to 1.305 million jobs in 2009 as a result of the lingering effects of the global recession (Figure 12). This represented average annual job growth of 0.5 percent over the entire nine-year period. However, total employment impacts increased to the highest level ever in 2009, reflecting a dramatic increase in exports of Florida products to domestic and world markets, and representing a 1.8 percent average annual growth during 2001-2009. Total value added impacts grew from $\$ 77.07$ billion in 2001 to $\$ 107.21$ billion in 2009 , or at a 4.9 percent average annual rate in inflation-adjusted terms (Figure 13). Among industry groups, average annual growth in value added impacts during 2001-2009 was highest for Agricultural Inputs and Services (14.9\%), followed by Mining (11.5\%) and Food and Kindred Products Distribution (6.7\%), while groups with low or negative growth during this period were Crop, Livestock, Fisheries, and Forestry Production (-1.4\%); Nature-based Recreation (-2.0\%); and Food and Kindred Product Manufacturing (1.6\%).

Of particular interest are the changes occurring for the recent period from 2007 to 2009, partly reflecting the effect of the global recession, which technically started in the United States in December 2007 and ended in September 2009. 


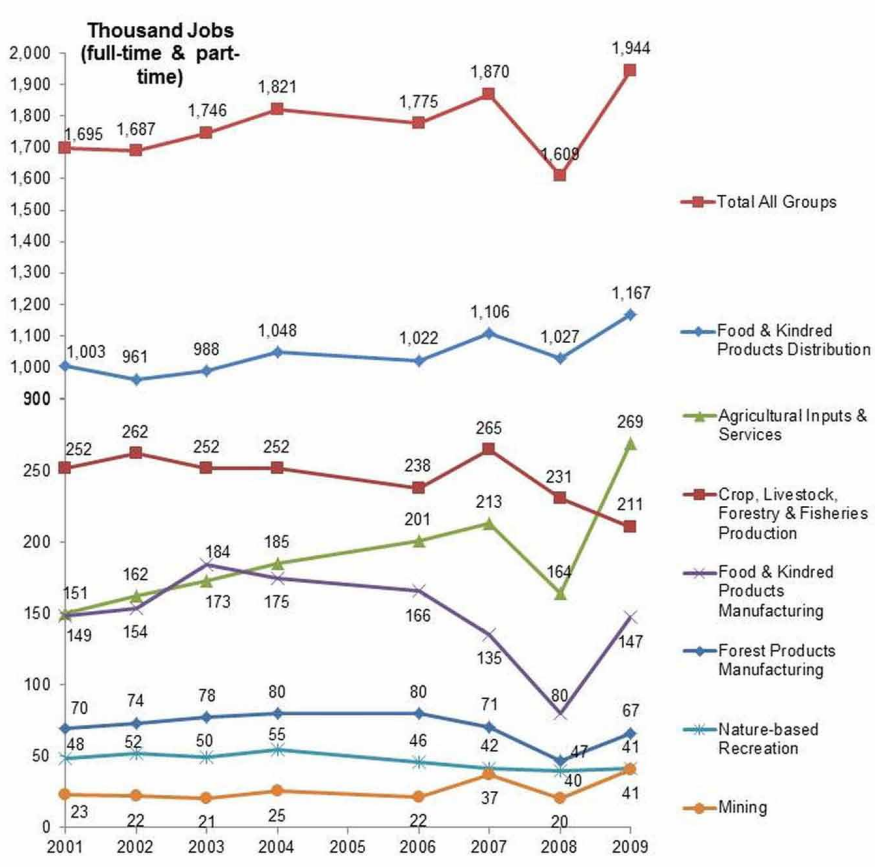

Figure 12. Trends in employment contributions by agriculture, natural resources, and related industries in Florida, 2001-2009. Source: IMPLAN data for Florida (Data unavailable for 2005. Estimates include regional multiplier effects)

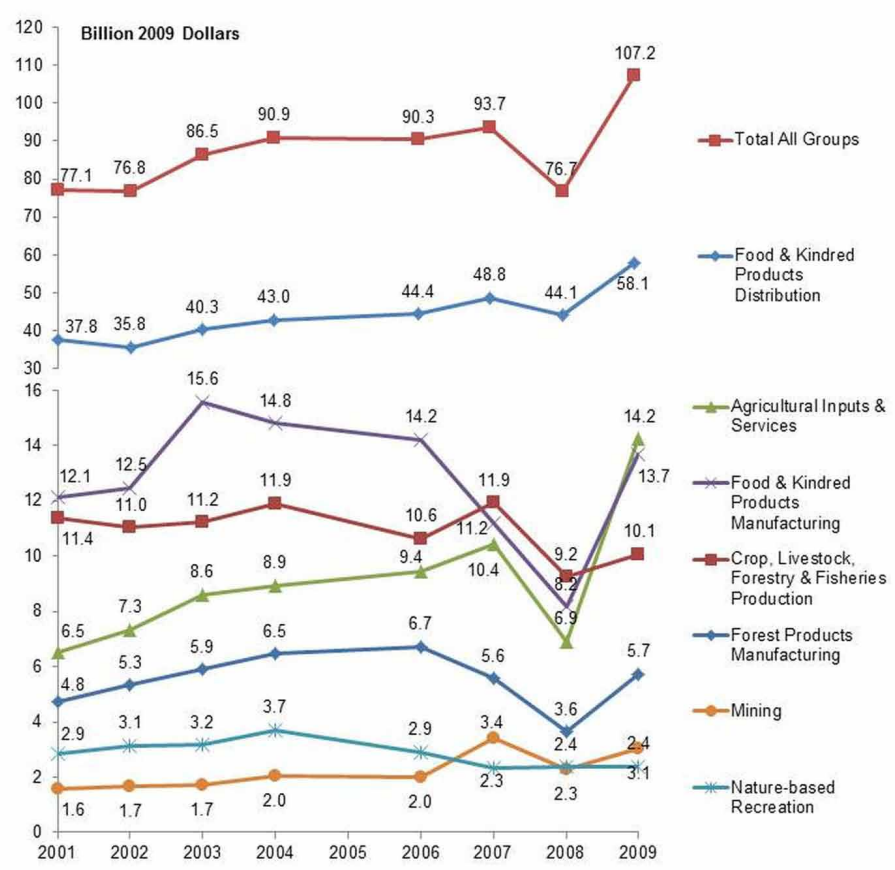

Figure 13. Trends in value added contributions by agriculture, natural resources, and related industries in Florida, 2001-2009. Source: IMPLAN data for Florida (Data unavailable for 2005. Estimates include regional multiplier effects)

Average annual growth rates were estimated separately for the periods 2001-2007 and 2007-2009 to show the effects of the recession. Total output impacts for all agriculture, natural resource, and related sectors grew at an average rate of 5.2 percent annually from 2001 to 2007 , but dropped to 3.6 percent from 2007 to 2009 . Interestingly, however, total employment and value impacts actually accelerated during the recession period (2007-2009) - employment impacts increased by 1.2 percent annually from 2001 to 2007 , and by 2.0 percent annually during 2007-2009, while total value-added impacts grew at an average annual rate of 3.6 percent during 2001-2007, and then increased to 7.2 percent during 2007-2009. These increased growth rates for both employment and value added impacts, particularly in 2008-2009, were due to dramatically expanded exports as the rest of the U.S. and international economies began to recover from recession.

Among groups within the agriculture, natural resources, and related industries, average annual growth in value added impacts from 2001 to 2007 was highest for Mining (19.0\%) and Agricultural Inputs and Services (10.1\%), followed by Food and Kindred Products Distribution (4.8\%) and Forest Product Manufacturing (2.9\%). However, from 2007 to 2009, Agricultural Inputs and Services had the highest average annual growth in value added impacts (18.1\%), followed by Food and Kindred Products Manufacturing (11.0\%) and Food and Kindred Products Distribution (9.5\%), while Crop, Livestock, Forestry, and Fisheries Production and Mining suffered the largest setbacks, with value added impacts declining by 7.8 percent and 5.2 percent, respectively. From 2007 to 2009, employment impacts increased the most for Agricultural Inputs and Services (13.2\%), Mining (5.2\%), and Food and Kindred Products Manufacturing (4.5\%), while Crop, Livestock, Forestry, and Fisheries Production had a large decline $(-10.2 \%)$, as did Forest Products Manufacturing (-2.9\%).

Trends in employment impacts of food and fiber commodity groups in Florida are shown in Figure 14. Environmental Horticulture, Fruit and Vegetable Farming and Processing, and Forestry, Wood and Paper Products Manufacturing experienced growth in employment impacts, value added impacts and output impacts in 2009, compared with 2008. From 2007 to 2009, Grain and Oilseed Farming, and Processing had the highest annual average growth in employment impacts (27.9\%), value added impacts (28.7\%), and output impacts (33.4\%). Sugarcane Farming, Refined Sugar, and Confections showed declines in employment impacts $(-26.8 \%)$, value added impacts $(-33.1 \%)$, and output impacts $(-25.0 \%)$.

Among individual industry sectors, the effect of the recession from 2007 to 2009 varied widely. While most sectors experienced a decline during this period, some sectors grew noticeably. Sectors with the highest growth in value 


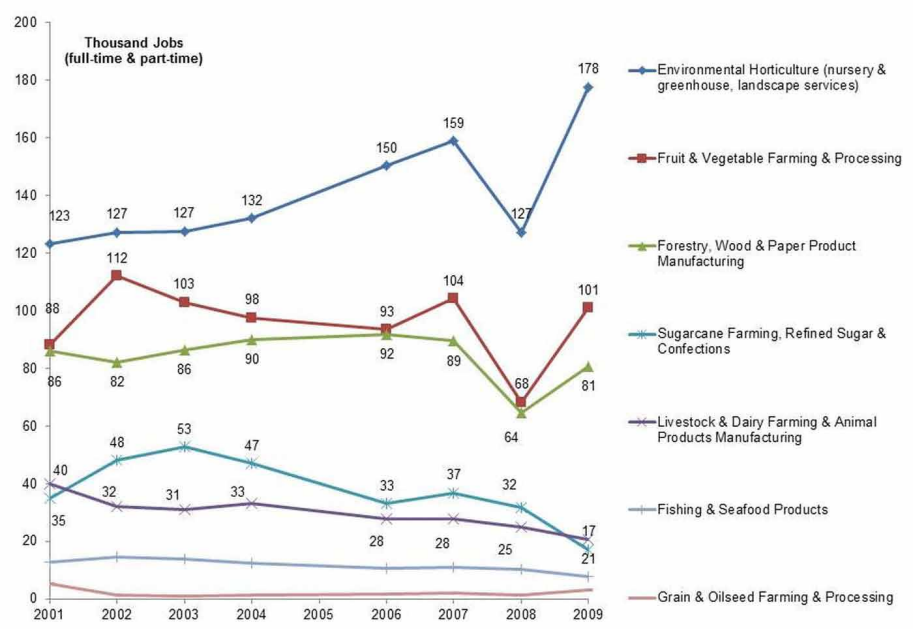

Figure 14. Trends in employment contributions by food and fiber commodity groups in Florida in 2001-2009. Source: IMPLAN data for Florida (Data unavailable for 2005. Estimates include regional multiplier effects)

added impacts were Tree nut farming (235\%), Fluid milk and butter manufacturing (163\%), Fats and oils refining and blending (144\%), Support activities for other mining (98\%), and Lawn and garden equipment manufacturing (96\%); however, these sectors were rather small. Sectors with the highest decline in value added impacts were Dog and cat food manufacturing (-46\%), Sugar manufacturing (-42\%), Support activities for oil and gas operations (-40\%), Cheese manufacturing (-46\%), Commercial hunting and trapping $(-38 \%)$, and Animal production except cattle and poultry $(-32 \%)$.

The average annual growth rate in direct value added for agriculture, natural resources, and related industries for 2001-2007 was 3.3 percent, but then fell to 1.6 percent for 2007-2009. In comparison, growth in direct value added during 2007-2009 for other major industry groups was higher for Education (9.9\%), Financial Services (7.8\%), Health Care and Social Services (4.8\%), and Real Estate and Renting (2.1\%), while negative growth was observed for Construction (-16.3\%), Management and Administrative Services (-8.7\%), Utilities (-4.2\%), Retail Trade (-3.0\%), Wholesale Trade (-2.6), Travel and Entertainment Services $(-2.2 \%)$, and Professional and Technical Services (-1.5\%).

\section{Conclusions}

This analysis indicated that agriculture and natural resources are linked to a broad array of economic sectors for commodity production, food and kindred product manufacturing, distribution, and related service activities. These industries collectively had a significant economic impact on the Florida economy in 2009, with direct employment accounting for about 13.4 percent of total employment and direct value added representing 8.5 percent of Gross State Product. Food and Kindred Products Distribution was by far the largest segment of the industry, representing 54 percent of value added and 60 percent of employment impacts. These industries are present throughout the state, with major activity in urbanized metropolitan areas as well as rural counties where it may be relatively more important as a share of total economic activity, although less so in absolute magnitude. The agriculture, natural resources, and related industries have grown substantially since 2001, with an interruption in 2008 by the global recession, and then recovering strongly in 2009 , with total regional economic impacts increasing dramatically due to increased exports. Growth in economic activity of agriculture, natural resources, and related industries during 2007-2009 was higher than most other major industry groups in terms of value added, thus entailing their integral contributions towards the sustainability of the Florida economy.

\section{References}

Hodges, A.W. and M. Rahmani. 2010. Economic contributions of Florida's agricultural, natural resource, food and kindred product manufacturing and distribution, and service industries in 2008. Electronic Data Information Source (EDIS) FE829. Gainesville, FL: UF/IFAS. http://edis. ifas.ufl.edu/FE829

Hodges, A.W. and M. Rahmani. 2009. Economic contributions of Florida's agricultural, natural resource, food and kindred product manufacturing and distribution, and service industries in 2007. Electronic Data Information Source (EDIS) FE800. Gainesville, FL: UF/IFAS. http://edis. ifas.ufl.edu/FE800

Hodges, A.W., M. Rahmani, and W.D. Mulkey. 2008. Economic contributions of agricultural, food manufacturing, and natural resource industries in Florida in 2006. Electronic Data Information Source (EDIS) FE702. Gainesville, FL: UF/IFAS. http://edis.ifas.ufl.edu/FE702

Johnson, K. and J. Kort. 2004. Redefinition of the BEA Economic Areas. Survey of Current Business. United States Department of Commerce, Bureau of Economic Analysis, Washington, D.C. (November). http://www.bea.gov/scb/ pdf/2004/11November/1104Econ-Areas.pdf

Minnesota IMPLAN Group, Inc. (MIG). 2010. IMPLAN Professional software for impact analysis and social accounting (Version 3.0) and Florida state and county data 
for 2001-2009. Minnesota IMPLAN Group, Inc., Stillwater, MN. http://www.implan.com

Miller, R.E. and P.D. Blair. 2009. Input-Output Analysis: Foundations and Extensions, Second Edition. Cambridge, UK: Cambridge University Press.

United States Department of Commerce, Bureau of Economic Analysis, (USDOC/BEA). 1970-2009 Gross Domestic Product Implicit Price Deflator. United States Department of Commerce, Bureau of Economic Analysis, Washington, D.C. http://research.stlouisfed.org/fred/data/gdp/gdpdef

Watson, P., J. Wilson, D. Thilmany, and S. Winter. 2007. Determining economic contributions and impacts: What is the difference and why do we care? Journal of Regional Analysis and Policy 37(2): 140-146. http://www.jrapjournal.org/pastvolumes/2000/v37/F37-2-6.pdf

\section{Appendix: Glossary of Economic Impact Terms}

Apparent consumption represents the consumption of any particular commodity in a region, and is calculated as the local output, plus imports and minus exports.

Employee compensation is comprised of wages, salaries, commissions, and benefits such as health and life insurance, retirement, and other forms of cash or non-cash compensation.

Employment is a measure of the number of jobs involved, including full-time, part-time, and seasonal positions. It is not a measure of full-time equivalents (FTE).

Exports are sales of goods to customers outside the region in which they are produced, which represents a net inflow of money to the region. This also applies to sales of services to customers visiting from other regions.

Final Demand represents sales to final consumers, including households and governments, and exports from the region.

Gross Regional Product is a measure of total economic activity in a region, or total income generated by all goods and services. It represents the sum of total value added contributions by all industries in that region, and is equivalent to Gross Domestic Product for the nation.

IMPLAN is a computer-based input-output modeling system that enables users to create regional economic models and multipliers for any region consisting of one or more counties or states in the United States. The current version of the IMPLAN software, Version 3.0, accounts for commodity production and consumption for 440 industry sectors; 10 household income levels; taxes to local, state, and federal governments; capital investment; imports and exports; transfer payments; and business inventories. Regional datasets for individual counties or states are purchased separately.

Impact or total impact is the change in total regional economic activity (e.g., output or employment) resulting from a change in final demand, direct industry output, or direct employment, where estimates are based on regional economic multipliers.

Imports are purchases of goods and services originating outside the region of analysis.

Income is the money earned within the region from production and sales.

Total income includes labor income such as wages, salaries, employee benefits, and business proprietor income, plus other property income.

Other property income represents income received from investments, such as corporate dividends, royalties, property rentals, or interest on loans.

Indirect business taxes are taxes paid to governments by individuals or businesses for property, excise, and sales taxes, but do not include income taxes.

Input-Output (I-O) model and Social Accounting Matrix (SAM) together are a representation of the transactions between industry sectors within a region that captures what each sector purchases from every other sector in order to produce its output of goods or services. Using such a model, flows of economic activity associated with any change in spending may be traced backwards through the supply chain.

Intermediate sales are sales to other industrial sectors. The value of intermediate sales is netted-out of Total Value Added.

Local refers to goods and services that are sourced from within the region, which may be defined as a county, multi-county cluster, or state. 
Non-local refers to economic activity originating outside the region.

Margins represent the portion of the purchaser price accruing to the retailer, wholesaler, and producer/manufacturer, in the supply chain. Typically, only the retail margins of many goods purchased by consumers accrue to the local region, as the wholesaler, shipper, and manufacturer often lie outside the local area.

Multipliers capture the total effects, both direct and secondary, in a given region, generally as a ratio of the total change in economic activity in the region relative to the direct change. Multipliers are derived from an I-O model of the regional economy. Multipliers may be expressed as ratios of sales, income, or employment, or as ratios of total income or employment changes relative to direct sales. Multipliers express the degree of interdependency between sectors in a region's economy and therefore vary considerably across regions and sectors. A sector-specific multiplier gives the total changes to the economy associated with a unit change in output or employment in a given sector (i.e., the direct economic effect) being evaluated. Indirect effects multipliers represent the changes in sales, income, or employment within the region in backward-linked industries supplying goods and services to businesses (e.g., increased sales in input supply firms resulting from more nursery industry sales). Induced effects multipliers represent the increased sales within the region from household spending of the income earned in the direct and supporting industries for housing, utilities, food, etc. An imputed multiplier is calculated as the ratio of the total impact divided by direct effect for any given measure (e.g., output, employment).

Output is the dollar value of a good or service produced or sold, and is equivalent to sales revenues plus changes in business inventories.

Output-consumption ratio is the total industry output divided by the apparent consumption for any given commodity or industry, and is a measure of the degree to which local demands are met by local production.

Producer prices are the prices paid for goods at the factory or point of production. For manufactured goods, the purchaser price equals the producer price plus a retail margin, a wholesale margin, and a transportation margin. For services, the producer and purchaser prices are equivalent.

Proprietor income is income received by non-incorporated private business owners or self-employed individuals.
Purchaser prices are the prices paid by the final consumer of a good or service.

Region defines the geographic area for which impacts are estimated, usually an aggregation of several counties defined on the basis of worker commuting patterns.

Sector is an individual industry or group of industries that produce similar products or services, or have similar production processes. Sectors are classified according to the North American Industrial Classification System (NAICS).

Value Added is a broad measure of income, representing the sum of employee compensation, proprietor income, other property income, indirect business taxes, and capital consumption (depreciation). Value added is a commonly used measure of the contribution of an industry to the regional economy because it avoids double counting of intermediate sales. 


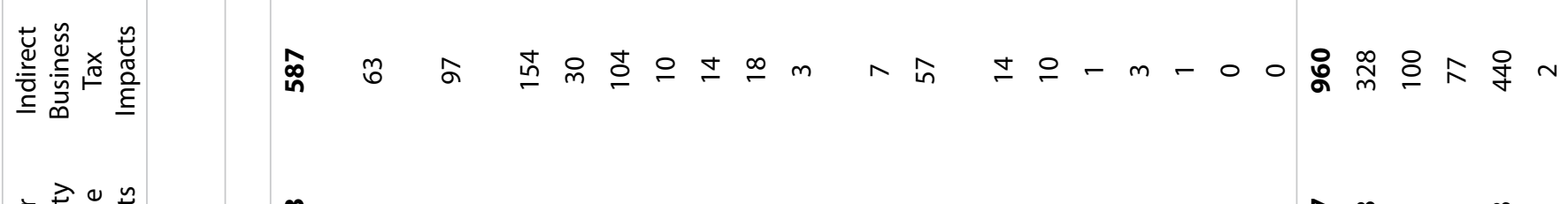

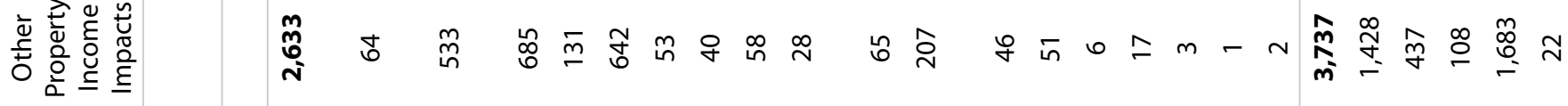

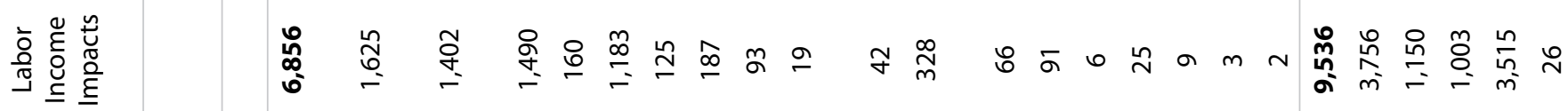

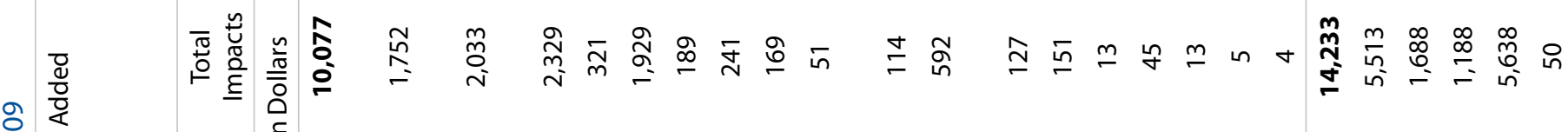

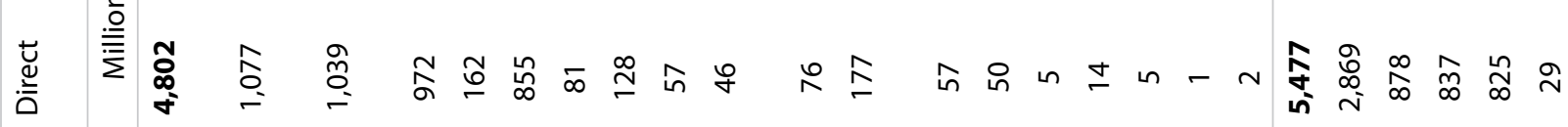

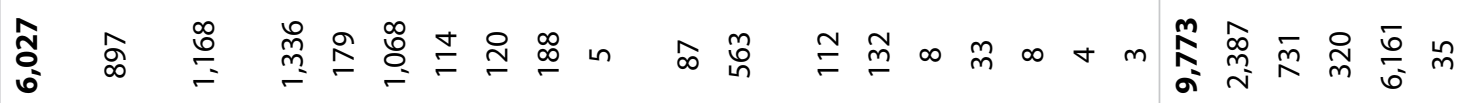

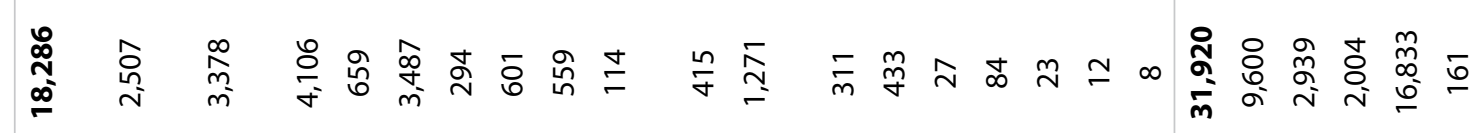

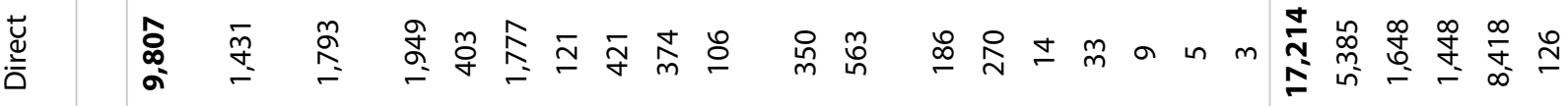

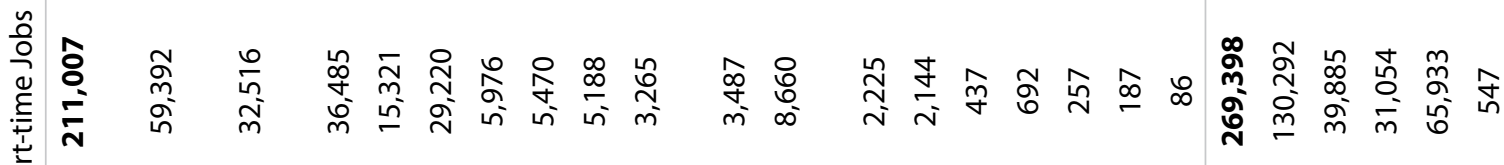

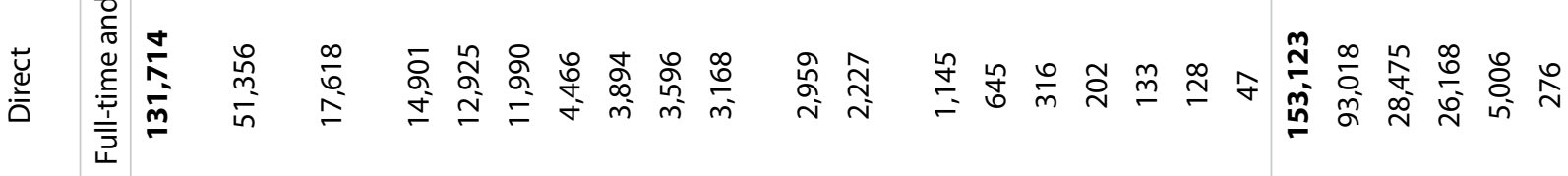

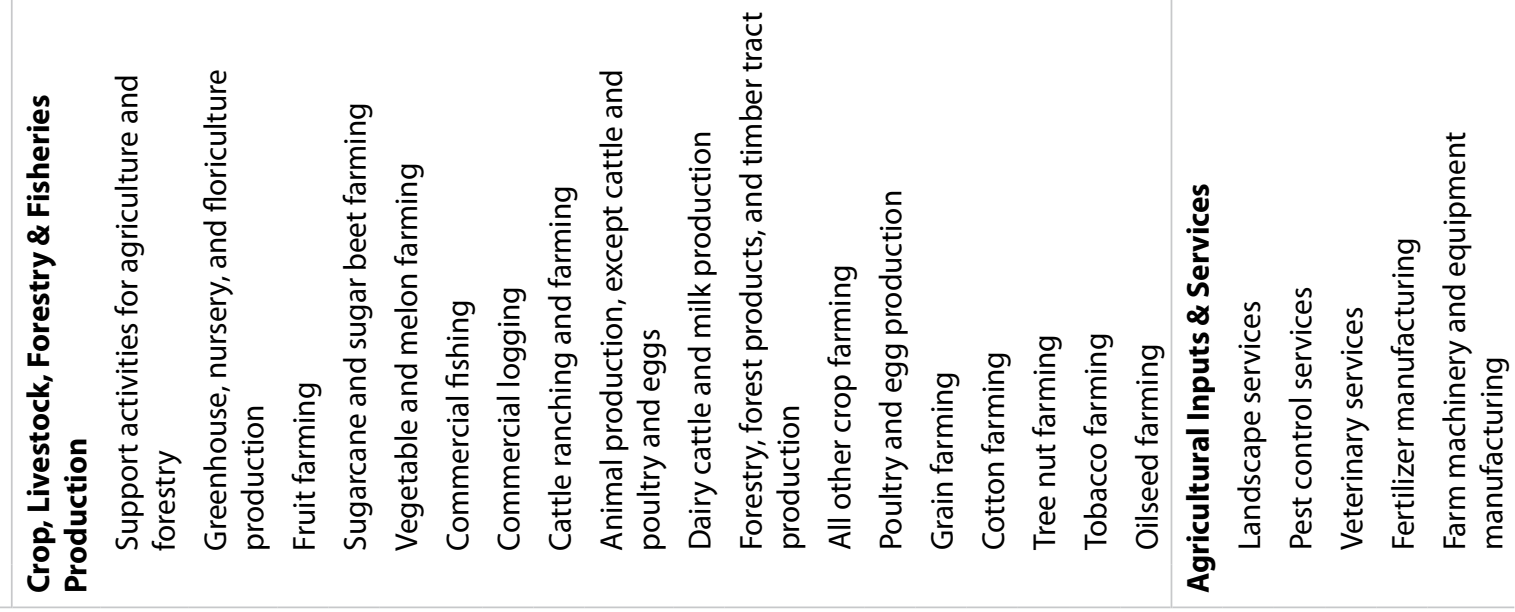




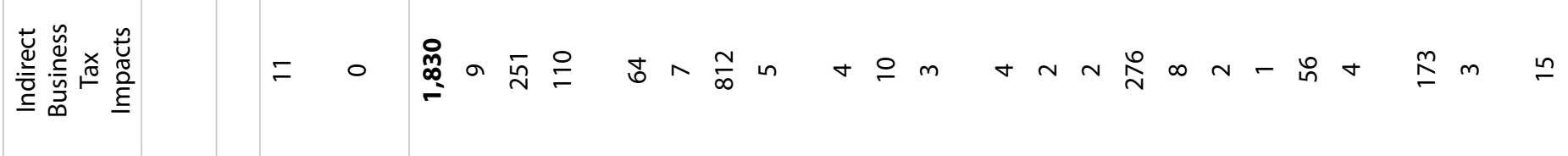

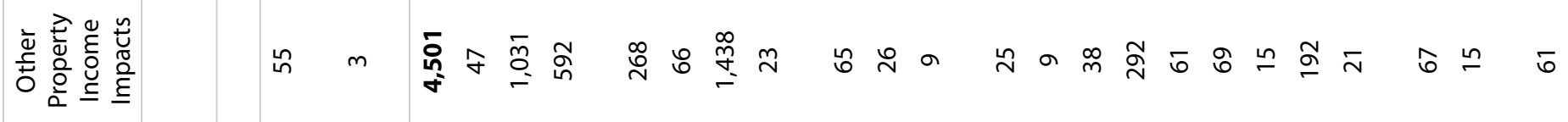

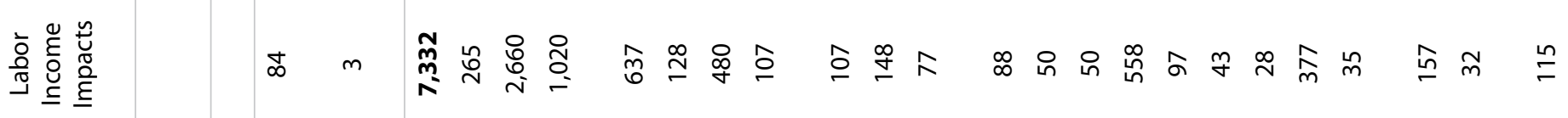

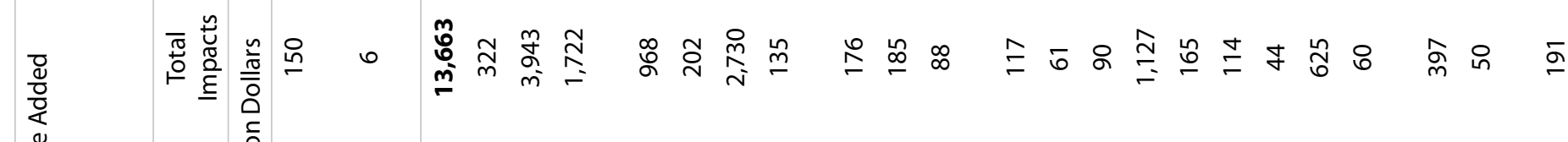

$\frac{9}{\frac{9}{5}}$

䓂 旁

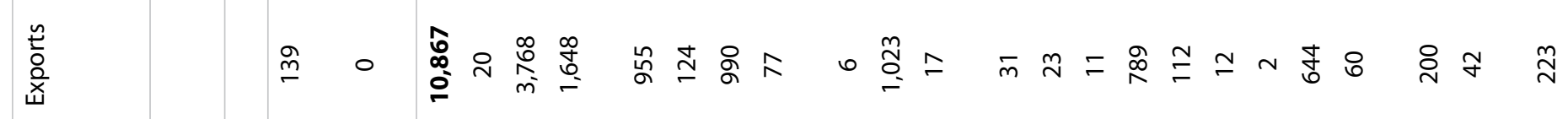

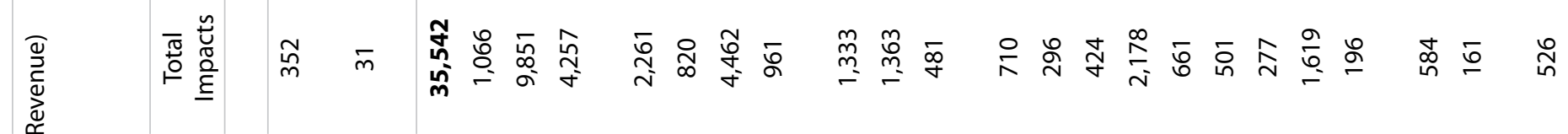

䓂 $\quad$ 旁

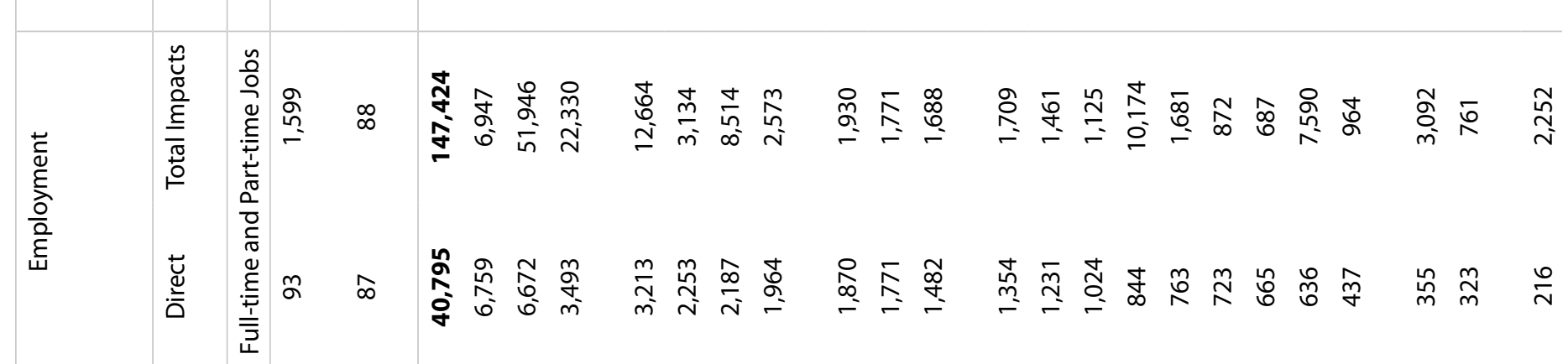

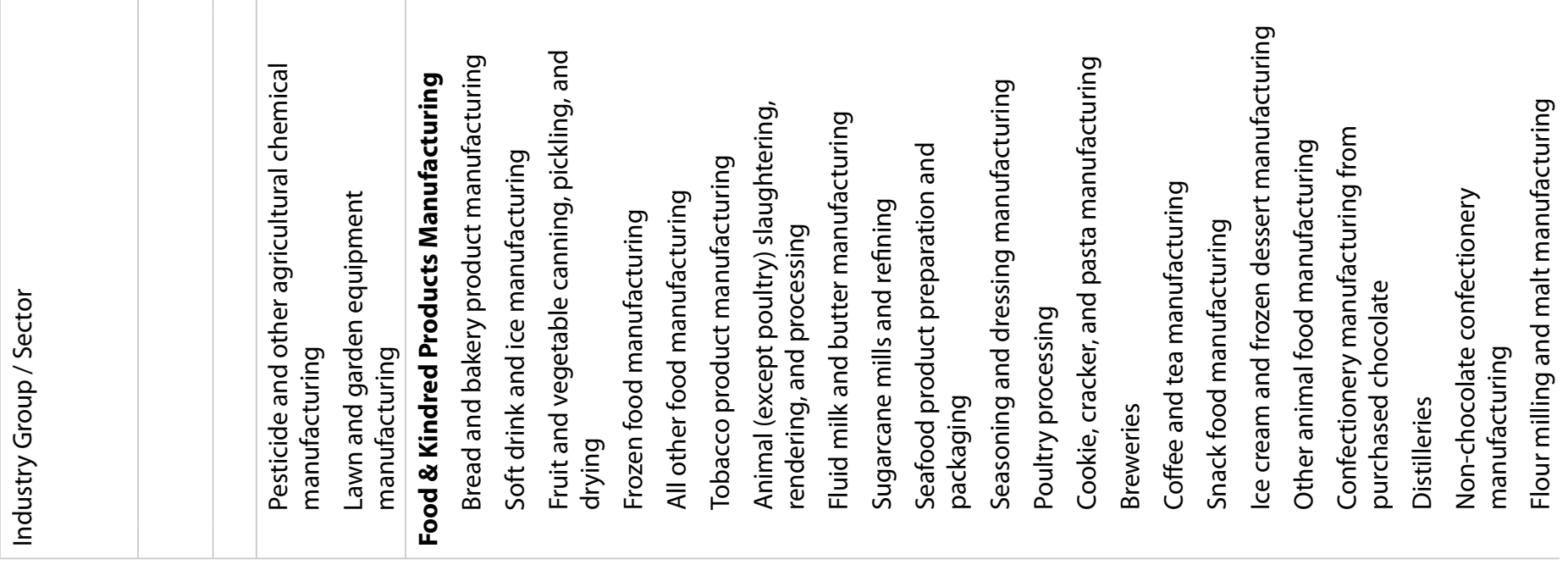




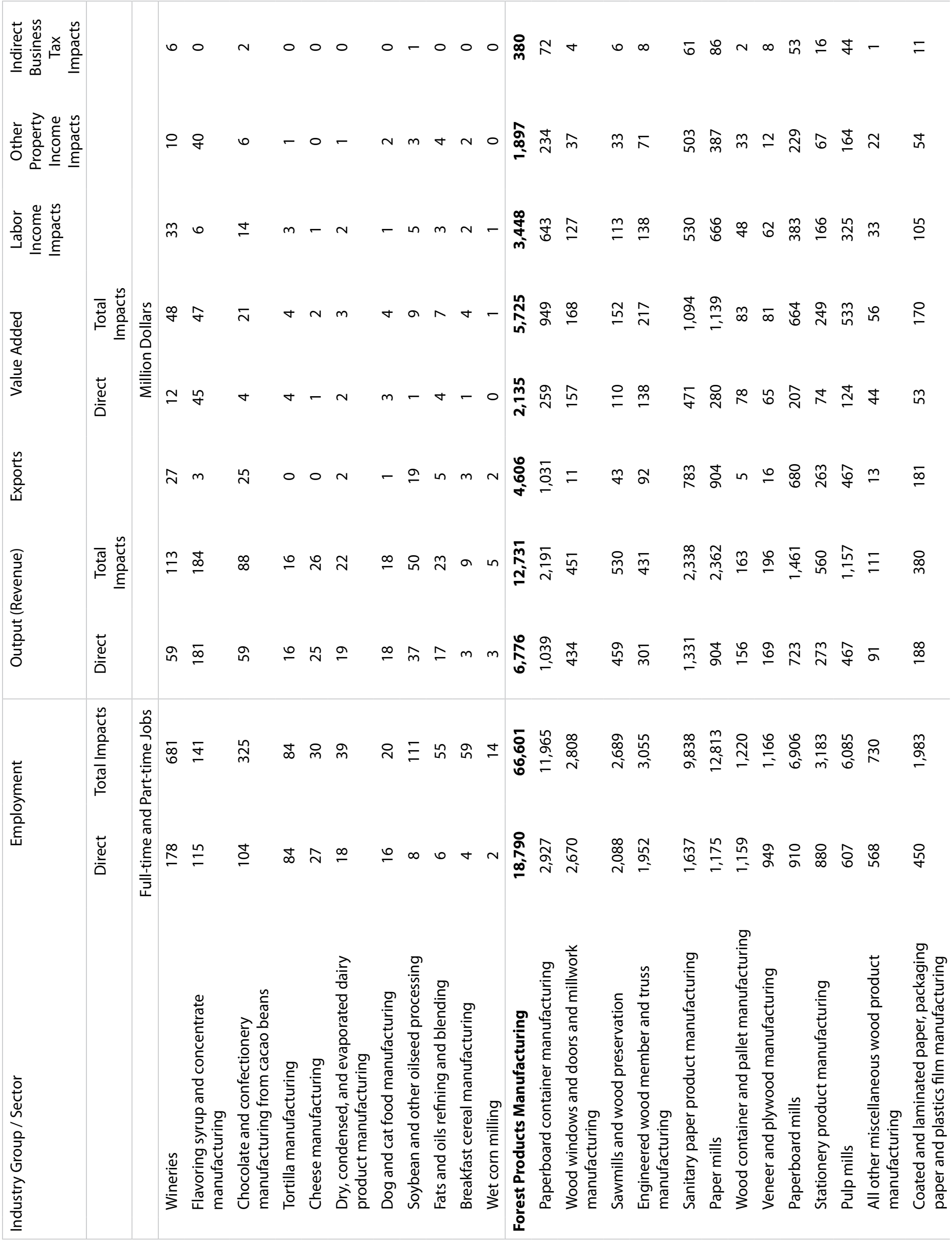




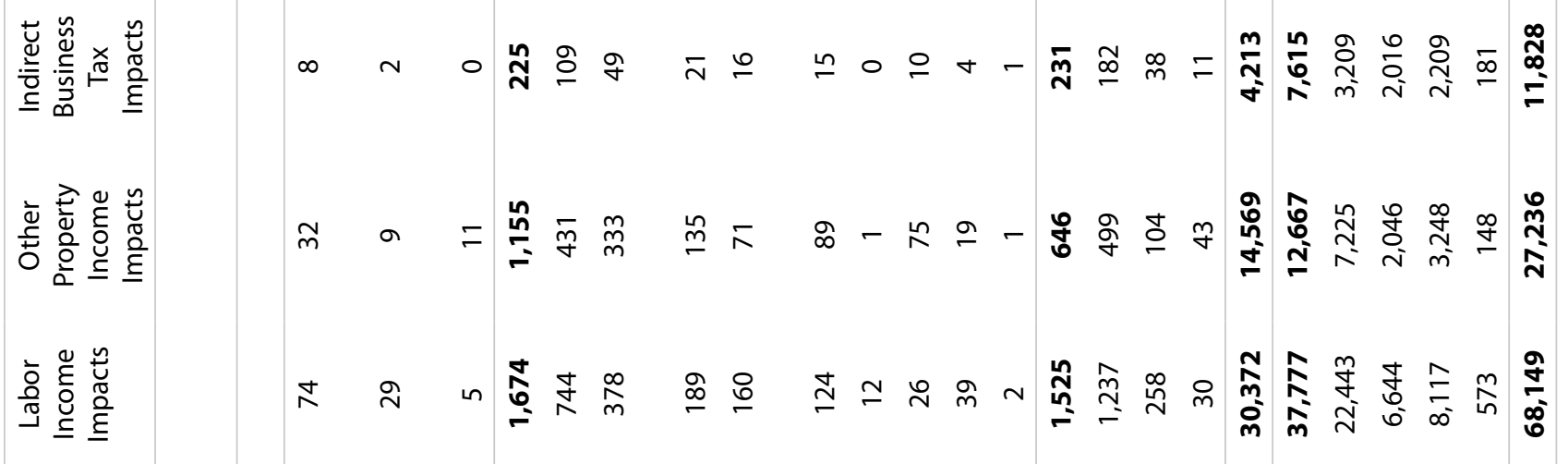

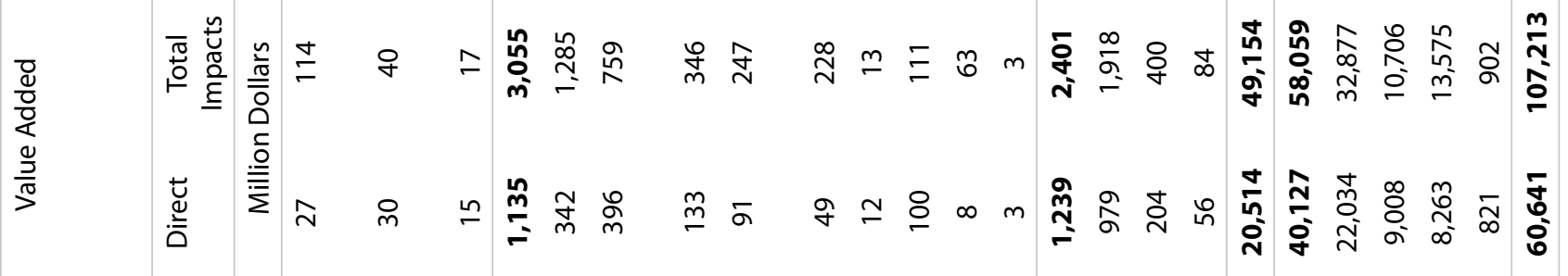

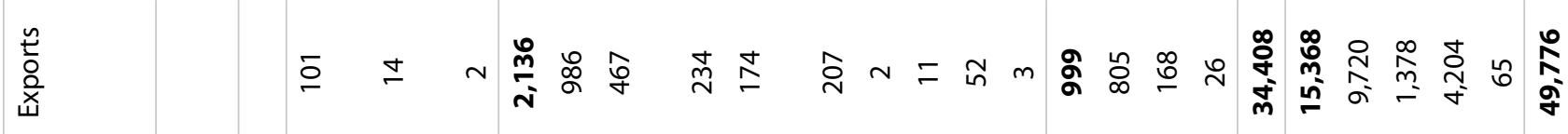

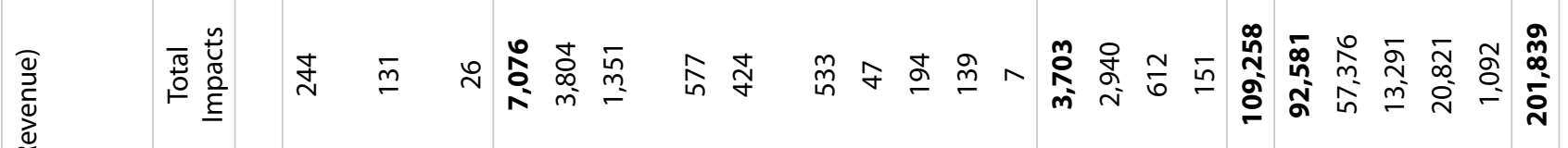

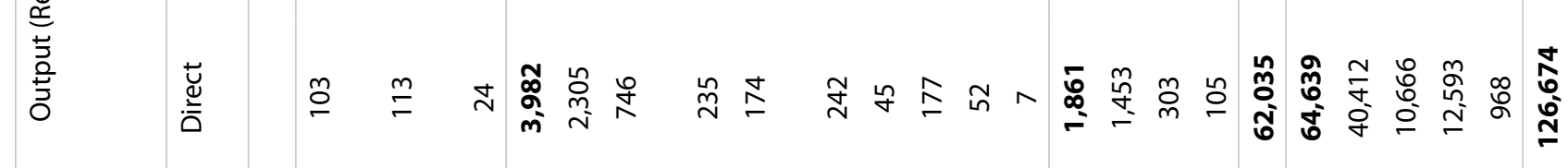

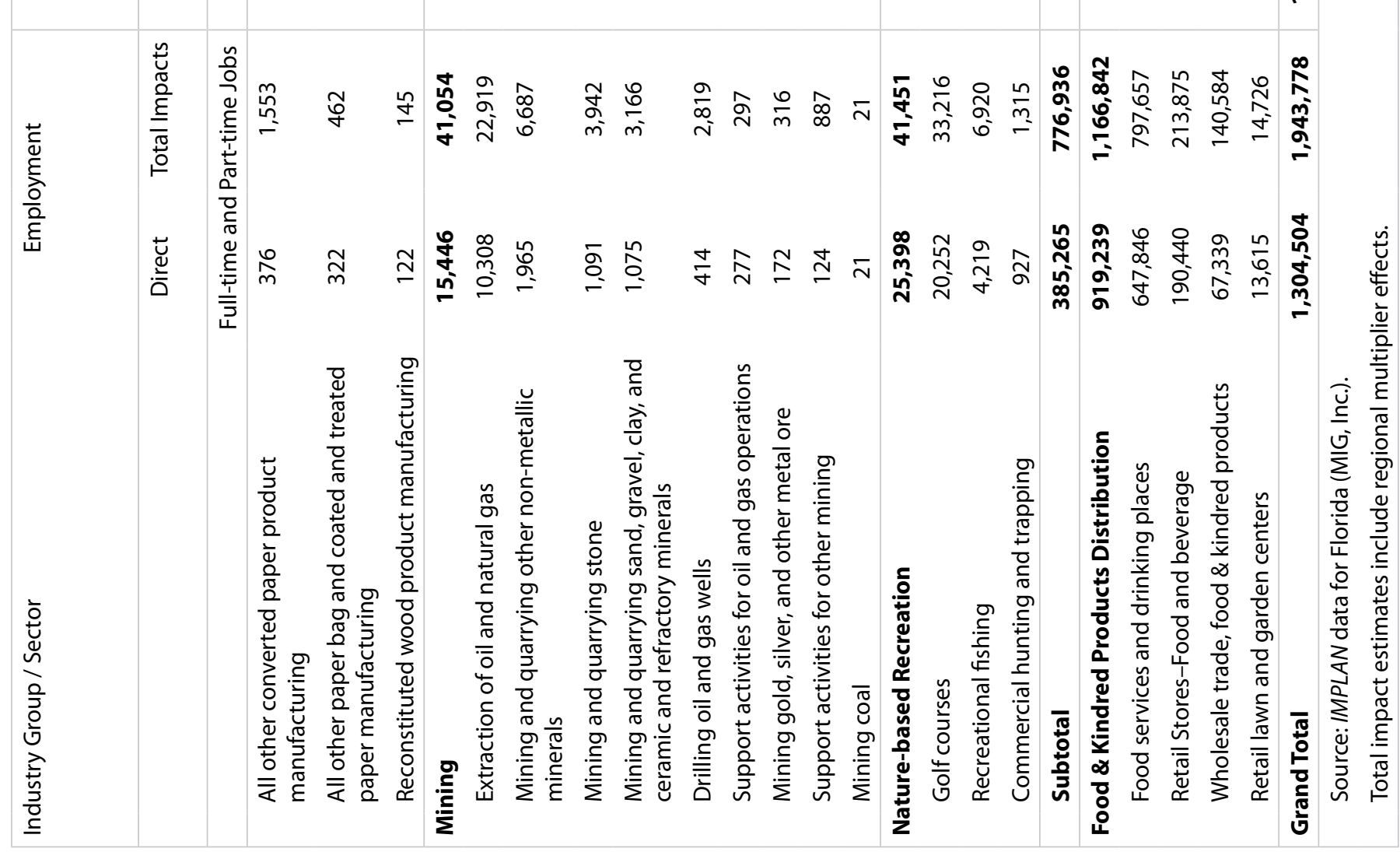


Table 2. Employment contributions in Florida regions and counties by agriculture, natural resources, and related industries, 2009

\begin{tabular}{|c|c|c|c|c|c|c|c|c|}
\hline \multirow[t]{2}{*}{ Region / County } & $\begin{array}{c}\text { Crop, } \\
\text { Livestock, } \\
\text { Forestry } \\
\text { \& Fisheries } \\
\text { Production }\end{array}$ & $\begin{array}{l}\text { Agricultural } \\
\text { Inputs \& } \\
\text { Services }\end{array}$ & $\begin{array}{l}\text { Food \& } \\
\text { Kindred } \\
\text { Products } \\
\text { Manufac- } \\
\text { turing }\end{array}$ & $\begin{array}{l}\text { Forest } \\
\text { Products } \\
\text { Manufac- } \\
\text { turing }\end{array}$ & Mining & $\begin{array}{c}\text { Nature- } \\
\text { based } \\
\text { Recreation }\end{array}$ & $\begin{array}{c}\text { Food \& } \\
\text { Kindred } \\
\text { Products } \\
\text { Distribution }\end{array}$ & Total \\
\hline & \multicolumn{8}{|c|}{ (Full-time and Part-time Jobs) } \\
\hline Gainesville & 17,545 & 4,228 & 3,725 & 2,690 & 1,009 & 419 & 25,701 & 55,316 \\
\hline Alachua & 2,197 & 2,922 & 277 & 744 & 147 & 53 & 17,943 & 24,284 \\
\hline Bradford & 479 & 117 & 90 & 253 & 719 & 21 & 1,055 & 2,734 \\
\hline Columbia & 1,192 & 204 & 470 & 544 & 4 & 47 & 2,908 & 5,369 \\
\hline De Soto & 5,460 & 152 & 616 & 0 & 2 & 46 & 566 & 6,842 \\
\hline Dixie & 975 & 14 & 5 & 788 & 7 & 5 & 367 & 2,160 \\
\hline Gilchrist & 758 & 200 & 2 & 83 & 3 & 23 & 263 & 1,332 \\
\hline Lafayette & 712 & 189 & 3 & 26 & 56 & 20 & 158 & 1,163 \\
\hline Levy & 1,882 & 163 & 32 & 51 & 24 & 6 & 1,166 & 3,325 \\
\hline Suwannee & 3,669 & 181 & 2,223 & 10 & 43 & 190 & 1,096 & 7,411 \\
\hline Union & 221 & 86 & 8 & 191 & 4 & 8 & 179 & 696 \\
\hline Jacksonville & 5,085 & 12,347 & 35,632 & 13,593 & 1,270 & 1,825 & 84,361 & 154,113 \\
\hline Baker & 248 & 80 & 0 & 0 & 0 & 0 & 696 & 1,024 \\
\hline Clay & 542 & 1,252 & 474 & 11 & 628 & 108 & 7,553 & 10,569 \\
\hline Duval & 982 & 8,564 & 34,897 & 6,772 & 551 & 754 & 59,146 & 111,667 \\
\hline Nassau & 1,170 & 556 & 88 & 3,885 & 2 & 101 & 2,976 & 8,779 \\
\hline Putnam & 1,011 & 407 & 36 & 2,648 & 36 & 48 & 1,996 & 6,181 \\
\hline St. Johns & 1,132 & 1,488 & 137 & 276 & 53 & 813 & 11,994 & 15,893 \\
\hline $\begin{array}{l}\text { Miami-Fort } \\
\text { Lauderdale }\end{array}$ & 71,938 & 64,081 & 45,211 & 8,450 & 3,196 & 13,627 & 377,898 & 584,402 \\
\hline Broward & 2,060 & 18,230 & 8,210 & 1,035 & 591 & 2,747 & 110,624 & 143,498 \\
\hline Glades & 1,107 & 17 & 23 & 0 & 11 & 22 & 110 & 1,291 \\
\hline Hendry & 13,216 & 280 & 2,984 & 0 & 61 & 15 & 1,418 & 17,974 \\
\hline Indian River & 7,479 & 2,450 & 221 & 39 & 103 & 824 & 6,173 & 17,289 \\
\hline Martin & 3,351 & 2,834 & 1,437 & 66 & 78 & 1,544 & 7,870 & 17,180 \\
\hline Miami-Dade & 13,587 & 16,939 & 14,898 & 6,021 & 1,483 & 1,408 & 154,497 & 208,833 \\
\hline Monroe & 1,386 & 884 & 80 & 11 & 169 & 386 & 11,103 & 14,020 \\
\hline Okeechobee & 3,116 & 358 & 616 & 0 & 62 & 30 & 1,477 & 5,658 \\
\hline Palm Beach & 20,465 & 19,695 & 15,464 & 1,114 & 537 & 6,158 & 75,538 & 138,971 \\
\hline St. Lucie & 6,169 & 2,394 & 1,279 & 164 & 102 & 493 & 9,088 & 19,689 \\
\hline Orlando & 54,007 & 63,810 & 37,569 & 9,920 & 6,204 & 7,348 & 268,272 & 447,129 \\
\hline Brevard & 789 & 3,266 & 388 & 159 & 88 & 995 & 24,911 & 30,596 \\
\hline Citrus & 511 & 703 & 4 & 218 & 118 & 324 & 4,489 & 6,367 \\
\hline Flagler & 1,121 & 871 & 34 & 74 & 84 & 164 & 2,880 & 5,229 \\
\hline Hardee & 5,730 & 192 & 132 & 151 & 421 & 31 & 566 & 7,222 \\
\hline Highlands & 9,410 & 439 & 110 & 246 & 211 & 250 & 3,294 & 13,961 \\
\hline Lake & 3,858 & 3,718 & 2,144 & 206 & 438 & 303 & 12,195 & 22,861 \\
\hline Marion & 6,226 & 3,610 & 1,501 & 558 & 309 & 740 & 12,297 & 25,241 \\
\hline Orange & 4,553 & 15,396 & 9,254 & 1,445 & 309 & 1,600 & 113,956 & 146,513 \\
\hline Osceola & 1,431 & 2,106 & 341 & 271 & 155 & 498 & 16,610 & 21,413 \\
\hline Polk & 15,787 & 21,144 & 21,329 & 4,974 & 3,679 & 889 & 21,028 & 88,831 \\
\hline
\end{tabular}




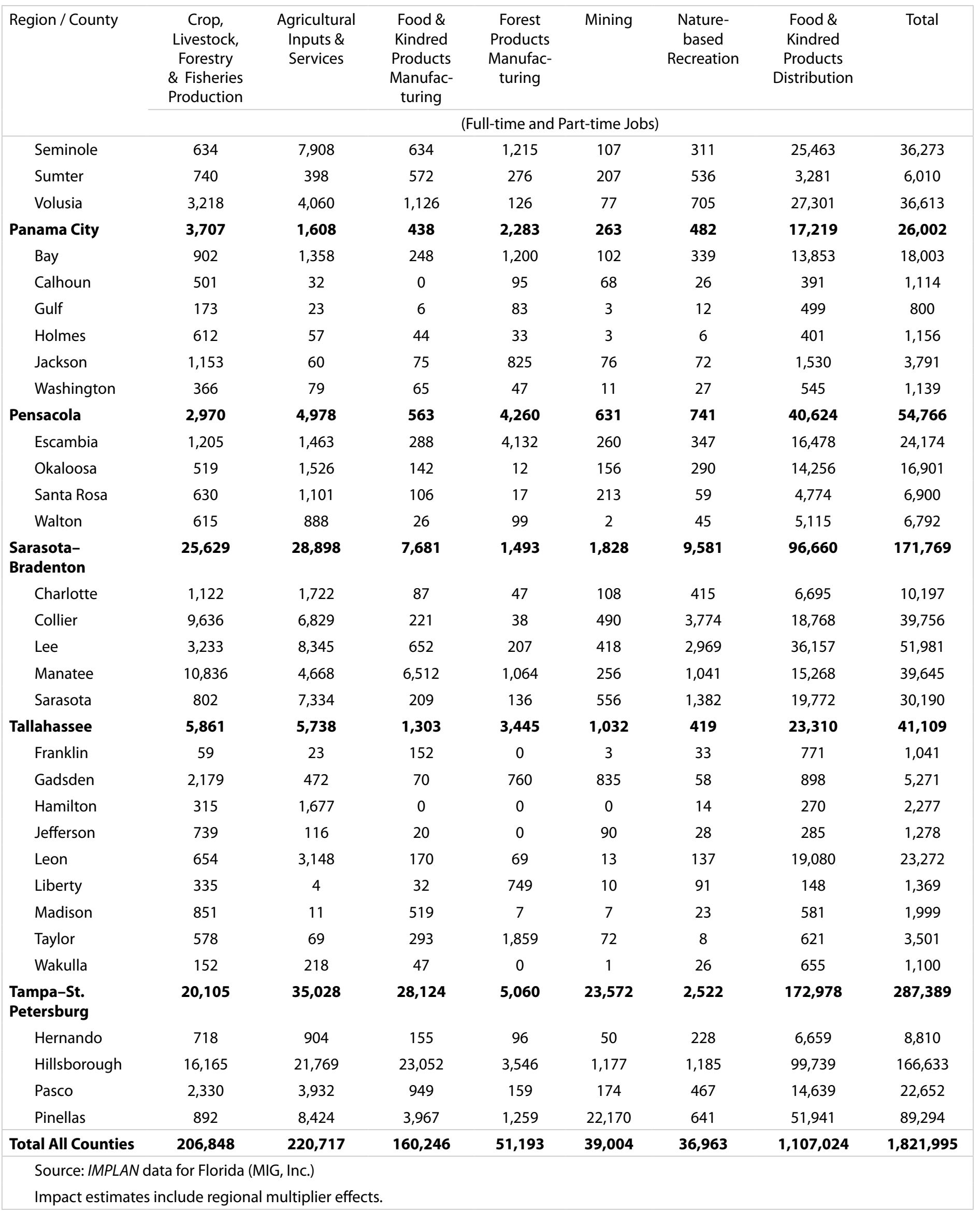

